\title{
Effect of Soil conditioners and Irrigation Levels on Growth and Productivity of Pomegranate Trees in the New Reclaimed Region
}

\author{
Abd-Ella E.K.Eman. ${ }^{1}$
}

\begin{abstract}
This investigation was carried out during 2010 and 2011 growing seasons on ten years old Arabi pomegranate trees, grown in sandy soil under drip irrigation in a private farm located at Alexandria-Matrouh road (about $80 \mathrm{Km}$ from Alex.). The experiment was designed to study the effects of different rates from soil conditioners, Hundz soil, $(0.0,0.5$ and $10 \mathrm{Kg} /$ tree) or mixture from (Nile fertile $\left.+\mathrm{K}_{2} \mathrm{SO}_{4}\right)[\mathrm{Zero},(2 \mathrm{Kg}+500 \mathrm{gm})$ and $(1 \mathrm{Kg}+250 \mathrm{gm})]$ under irrigation levels at 50,75 and $100 \%$ of the recommended water level $\left(5.5,8.25\right.$ and $11 \mathrm{~m}^{3} /$ tree /year $)$ as well as their interactions on growth, leaf component, flowering, fruiting, yield and fruit quality during both seasons. The results indicated that the highest irrigation level of $11 \mathrm{~m}^{3}$ /tree /year enhanced vegetative growth, fruit set, yield as well as leaf NPK content and fruit quality (fruit weight, diameter, length, TSS, anthocyanine and V.C.) while fruit acidity and tannins content decreased. Moreover, application of either Hundz soil at rate of $10 \mathrm{~kg} /$ tree or the mixture of $\left(\mathrm{NF}+\mathrm{K}_{2} \mathrm{SO}_{4}\right)$ at highest rate $(2 \mathrm{Kg}+500 \mathrm{gm})$ gave significantly the highest mean values of the above mentioned characters during the two seasons. Comparing with trees irrigated with $11 \mathrm{~m}^{3} /$ tree/year level, adding Hundz soil at $10 \mathrm{Kg} /$ tree under irrigation treatment $8.25 \mathrm{~m}^{3} /$ tree /year gave similar effect on improving all growth characters, fruit set, yield and fruit quality except fruit diameter and V.C. Similar results were found with high rate of the mixture $\left(2 \mathrm{Kg} \mathrm{NF}+500 \mathrm{gm} \mathrm{K}_{2} \mathrm{SO}_{4}\right)$ with the same level of irrigation on all characters except acidity. Date also indicated that the application of $\mathrm{Hz}$ soil combined with mixture of $\left(\mathrm{NF}+\mathrm{K}_{2} \mathrm{SO}_{4}\right)$ at both highest levels for each of them and irrigated with moderate irrigation level $8.25 \mathrm{~m}^{3}$ /tree /year gave best growth and produced higher fruit quality as compared with trees irrigated with $100 \%$ from recommended water level. Similar effects of combinations between high rate of both Hundz soil and the mixture of Nilefertile $+\mathrm{K}_{2} \mathrm{SO}_{4}$ under least irrigation treatments $5.5 \mathrm{~m}^{3}$ /tree/year on the previous characters of fruit. Data indicated generally that the best treatment combination was gained from using highest irrigation level $\left(11 \mathrm{~m}^{3} /\right.$ tree /year $)$ and $10 \mathrm{Kg} /$ tree Hundz soil $+2 \mathrm{Kg}$ /tree Nile Fertile $+500 \mathrm{gm} \mathrm{K}_{2} \mathrm{SO}_{4}$ which resulted in the highest values for all vegetative growth characters, leaf N P K, chlorophyll and RWC, yield and all fruit quality except leaf proline, juice tannins and acidity in both seasons. It could be recommended to apply $2 \mathrm{Kg}$ /tree Hundz soil combined with $2 \mathrm{Kg} \mathrm{NF}+500 \mathrm{gm} \mathrm{K} \mathrm{KO}_{4}$ with irrigation level of $11 \mathrm{~m}^{3} /$ tree /year to obtain highest production with good quality of pomegranate fruits as well as to apply $2 \mathrm{Kg}$ /tree Hundz soil with $2 \mathrm{Kg} \mathrm{NF}+500 \mathrm{~K}_{2} \mathrm{SO}_{4}$ under irrigation $8.25 \mathrm{~m}^{3} /$ tree /year or $5.5 \mathrm{~m}^{3} /$ tree /year for
\end{abstract}

saving about $25 \%-50 \%$ of water to achieve the same yield and fruit quality according to the availability of water, especially in the new reclaimed area.

\section{INTRODUCTION}

Water is one of the most important components in the biological function (Salisbury and Ross, 1985). Increasing water use efficiency, fruit management, production and saving irrigation water are important tasks (Devid et al., 1999). Of all the materials used by fruit trees, water seems to be taken up in the largest amounts (Chopade, 2001). Cultivation on arid sandy soil requires large quantities of water. The low water holding capacity of this soil causes rapid infiltration and deep percolation below the root zone (Beaumont, 1993). For production a high crops especially on the sandy soils, the physical-chemical properties of these soils must be modified. The addition of conditioners to such soils enhanced their properties, leading to decrease water infiltration rate, increasing the efficiency of the used water and fertilizers (Laila- Ali et al., 2009).

Recently, the global demand for clean agriculture free from chemical, like fertilizers, pesticides, synthetic soil conditioners, etc., is of much concern at moment to protect the ecosystem from their adverse effects hence, natural soil conditioners are the most effective agents in stabilizing soil organic matter (El-Aggory and Abd ElRasoul, 2002).Also, Khalifa et al., (1997) suggested that natural soil conditioners increased soil hydraulic conductivity and water diffusivity of sandy soil whereas Laila-Ali et al., (2009) found that applying the combinations of organic source and soil natural conditioners increase yield of wheat plant.

Thus, Hundz soil is a natural soil conditioner that is made out of dry compressed cellulose and recycles agricultural material, shaped in grains and varies in size $(0.2-2.0 \mathrm{~mm})$ that is capable of penetrating through the sand grains, forming a new media ideal for growing plants, has a balanced $\mathrm{pH}$ of 6.8-7.2, water holding capacity of $300 \%$ naturally, which will change sandy soil water capacity and does not absorb heat, so water evaporation is dramatically minimized. Hundzsoil retains water longer than regular soil, so plants develop healthy root system. Hundz soil is certified from Soil, Water and Environment Res., Institute, ARC, Giza Egypt. 
The second soil conditioner is Nilefertile which contains many components as sulfur fertilizer mixture (SFM) in a fine powder form, produced by Giza Technology Co. (Egypt) to be a good substitute for Nile mud (Abd-Allah, 1997). It's containing elemental sulfur (32\%)as an acidulous material which is oxidized slowly to sulfuric acid, after its application to soil, thio bacillus ,thio oxidants, autotrophic bacteria and different SOxidizing bacteria, which effective especially under alkaline conditions,Bentonite clay or mudstone (18\%) as a water absorbent material, a mixture of ground rocks and minerals $(45 \%)$ that are rich in fertilizer elements:P,K, Mg,Fe ,Ca and $\mathrm{Mn}$ and five percent of urea as a source of nitrogen.

As water supply is limited, loss of turgor and wilting are typical symptoms of potassium deficiency and this may be related to the role of $\mathrm{K}$ in stomatal regulation which is the major mechanism controlling the water regime of higher plants. In addition, potassium maintains higher tissue water content even under shortage of water (Lindhauer, 1985). Potassium is essential for the synthesis of amino acids, thus plants don't grow well in the absence of potassium (Edmond et al., 1975).A large number of enzymes is either completely dependent on or stimulated by K (Suelter, 1970).

So, the aim of the present study was designed to improve the main characteristics of sandy soil and to increase water use efficiency of pomegranate trees subjected to different irrigation frequencies and different levels of soil conditioners Handz soil, Nilefertile and $\mathrm{K}_{2} \mathrm{SO}_{4}$ on vegetative growth and fruit quality parameters. Also, to determine whether Handz soil can reduce irrigation frequencies without negative effect on yield and fruit quality.

\section{MATERIALS AND METHODS}

The present study was carried out during 2010 and 2011 successive seasons on ten years old Arabi pomegranate trees (granatumPunica L.), grown in sandy soil of a private farm located at Alex.-Matrouh road (about $80 \mathrm{Km}$ from Alex.).Trees under investigation were uniform in shape and size as possible, spaced at $5 \times 5$ meters apart and irrigated with drip irrigation. The physical and chemical properties of the experimental soil are presented in Table (1). The trees were annually fertilized with $15 \mathrm{~m} 3 /$ feddan of organic manure (sheep manure) in December of each year with $1.0 \mathrm{Kg} /$ tree calcium superphosphate $(15.5 \%$ $\left.\mathrm{P}_{2} \mathrm{O}_{2}\right)$.Also, $2.0 \mathrm{Kg}$ / tree ammonium sulphate $(20.6 \% \mathrm{~N})$ and $1.0 \mathrm{Kg}$ /tree of potassium sulphate $\left(48 \% \mathrm{~K}_{2} \mathrm{O}\right)$ were added in three equal doses at February, April and June. The following treatments were applied:
1-Irrigations frequencies were divided into three levels; $50 \%, 75 \%$ and $100 \%$ of the recommended rate of irrigations according to the recommendations of the Ministry of Agriculture as follows:

$\mathrm{I}_{1}: 50 \%$ of the recommended rate of irrigation $\left(5.5 \mathrm{~m}^{3}\right.$ $/$ tree $/$ year $)=924 \mathrm{~m}^{3} /$ feddan $/$ year.

$\mathrm{I}_{2}: 75 \%$ of the recommended rate of irrigation $\left(8.25 \mathrm{~m}^{3}\right.$ $/$ tree $/$ year $)=1389 \mathrm{~m}^{3} /$ feddan $/$ year.

$\mathrm{I}_{3}: 100 \%$ of the recommended rate of irrigation $\left(11.0 \mathrm{~m}^{3}\right.$ $/$ tree $/$ year $)=1848 \mathrm{~m}^{3} /$ feddan $/$ year.

Irrigation treatments varied with the change of the developmental stage of the plant.

2-Hundz soil (HN) conditioner was used at three levels:

$\mathrm{HN}_{0}$ : No addition (control treatment)

$\mathrm{HN}_{1}: 5 \mathrm{Kg} /$ tree Hundz soil

$\mathrm{HN}_{2}: 10 \mathrm{Kg} /$ tree Hundz soil

Hundz soil was applied to the soil under drip irrigation lines in January of each year. The chemical analysis of Hundz soil is shown in Table(2)

3- A mixture of Nilefertile $+\mathrm{K}_{2} \mathrm{SO}_{4}$ was applied together to the wet surface under drip irrigation line at three equal doses at March, May and July of both seasons at three rates:

$\mathrm{MX}_{0}$ : without any addition (control treatment)

$\mathrm{MX}_{1}: 1 \mathrm{Kg}$ of Nilefertile $+250 \mathrm{gm} \mathrm{K}_{2} \mathrm{SO}_{4} /$ tree

$\mathrm{MX}_{2}: 2 \mathrm{Kg}$ of Nilefertile $+500 \mathrm{gm} \mathrm{K}_{2} \mathrm{SO}_{4} /$ tree

The experimental design was a split-split-plots system in a randomized complete block design (RCBD) with three replications. The experiment consisted of twenty seven treatments; which representing the combinations among the three factors; the first one was the three irrigation levels which arranged as the main plots $\left(I_{1}, I_{2}\right.$ and $\left.I_{3}\right)$. The second one was Hundz soil levels $\left(\mathrm{HN}_{0}, \mathrm{HN}_{1}\right.$ and $\left.\mathrm{HN}_{2}\right)$ were considered as the subplot, while the third factor was three levels of the mixture of Nile fertile $+\mathrm{K}_{2} \mathrm{SO}_{4}\left(\mathrm{MX}_{0}, \mathrm{MX}_{1}\right.$ and $\left.\mathrm{MX}_{2}\right)$ were placed as sub - sub plots.

The following parameters were used to evaluate the tested treatments:

\section{1- vegetative growth}

In each season of study (on early April) four uniform branches were selected on each tree and tagged at their cardinal points. The average number of new shoots in each of the branches was counted. The length $(\mathrm{cm})$ and diameter $(\mathrm{cm})$ were measured as well as number of leaves/ shoot were counted. Ten leaves were collected randomly from the first mature leaves from the tip of the previously tagged shoots and their areas $\left(\mathrm{cm}^{2}\right)$ were measured. 


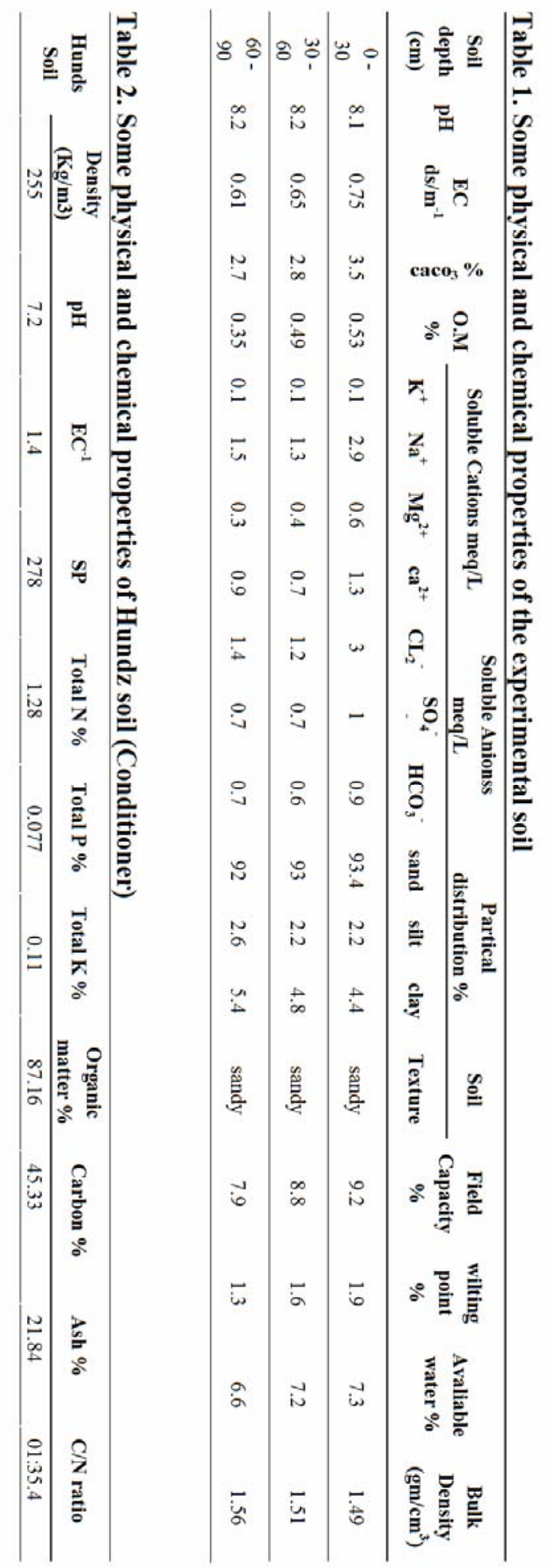




\section{2-Leaf chemical composition}

\subsection{Leaf chlorophyll and minerals content}

A sample of twenty mature leaves was randomly collected from the middle part of non-fruiting shoots of each replicate tree in May of both seasons to determined total leaf chlorophyll according to the method described by Yadava (1986) using Minolta Chlorophyll Meter Spad.502 (Minolta Camera, LTD Japan). The previous selected fresh leaves were washed with tap water, thereafter with distilled water and dried under a constant temperature $70^{\circ} \mathrm{C}$ in an electric oven. Each sample of dried leaves was ground to powder using porcelin mortar to avoid contamination. A sample of $0.3 \mathrm{gm}$ from the ground leaves was digested using $\mathrm{H}_{2} \mathrm{O}_{2}$ and $\mathrm{H}_{2} \mathrm{SO}_{4}$ according to Evenhuis and Dewaard (1980).Aliquots were then taken for mineral determination. Total nitrogen and phosphorus were determined colorimetrically according to Evenhuis (1976)and Murphy and Riley (1962), respectively. Potassium was determined against a standard using flame photometer following Chapman and Pratt, (1961). The concentrations of NPK were expressed as a percentage on dry weight bases.

\subsection{Determinationof free leaf proline content}

A sample of $0.5 \mathrm{gm}$ from the dried mature leaves was homogenized in $10 \mathrm{ml}$ sulphosalicylic acid (3.5\%) and centrifuged for 5 minutes at $300 \mathrm{rpm}$ and decanted then filtered through What-man no. 2 filter paper. The supernatant was diluted and injected in Beckman Amino Acid Analyzer 1/9CL. The proline concentration was determined from standard curve and calculated on dry weight basis according to Singh et al., (1973).

2.3. The leaf relative water content(RWC): was calculated as the method described by Smart and Bingham (1974). Ten mature leaves were taken from each replicate, cleaned with tissue paper and their fresh weight was immediately recorded. The turgid weight of these leaves was recorded after floating in water in covered petridish for 24 hours at $4^{\circ} \mathrm{C}$. Thereafter, the leaves were weighted and then dried at $70^{\circ} \mathrm{C}$ to a constant weight and their dry weights were recorded. The leaf relative water content (RWC) was calculated from the following equation:

$$
\text { RWC }=\frac{\text { Fresh weight }- \text { Dry weight }}{\text { Turgid weight }- \text { Dry weight }} \times 100
$$

\section{3-Flowering, fruit set percentages and yield}

The total number of flowers per shoot on each tagged branch was counted at full bloom. The numbers of set fruits on the same branches were recorded to calculate fruit set percentage according to the following equation
Fruit set $\%=($ No. of developing fruits $/$ total number of flowers $) \times 100$. Total yield $(\mathrm{kg})$ of each replicate tree was determined at fruit maturity stage at the $2^{\text {nd }}$ week of August.

\section{4-Fruit quality}

Samples of six fruits from each replicate at harvest time (mid-August) were taken to determine fruit weight $(\mathrm{gm})$, length $(\mathrm{cm})$, diameter $(\mathrm{cm})$ and volume $\left(\mathrm{cm}^{3}\right)$. In juice of each fruit sample, total soluble solids (TSS) percentage was determined by a hand refractometer and percentage of acidity was measured according to A.O.A.C. (1995).Vitamin C was determined by the titration with dichlorophenol indophenol blue dye and expressed as $\mathrm{mg}$ vitamin $\mathrm{C} / 100 \mathrm{ml}$ juice. Also, total anthocyanin percentage in fruit juice was determined as described by Hsia et al., (1965). Tannins content was measured in the juice by the method described by Winton and Winton, (1945).

Data were statistically analyzed using Co-Stat CoHort Software computer program for statistics (1986). The differences among the means of experimental treatments were separated by LSD test for interpretation of results as explained by Steel and Torrie (1980).

\section{RERSULTS AND DISCUSSION}

\section{1-Main effects of different factors on the studied characters}

The results of the main effects of the different studied factors;i.e.,soil conditioner(Hundz soil), irrigation frequency and mixture of Nilefertile $+\mathrm{K}_{2} \mathrm{SO}_{4}$ on vegetative growth,fruiting,yield, leaves chemical composition and fruit quality of pomegranate trees are shown in Tables 3 to 7 .

\section{1-Vegetative growth characters}

Concerning the main effects of the three studied factors;i.e.three irrigation levels, three Hundz soil rates and three levels of the mixture of Nilefertile $+\mathrm{K}_{2} \mathrm{SO}_{4}$ on vegetative growth characters (shoot length,diameter,no. of leaves /shoot,no. of shoots/main branch and leaf area) of pomegranate trees, the results generally illustrated that the comparisons among the mean values of the studied characters for each factor appeared to be significant, in both growing seasons(Table3).

The obtained results concerning the main effect of irrigation levels illustrated generally that the highest vegetative growth parameters resulted from the highest irrigation level $\mathrm{I}_{3} \quad\left(11 \mathrm{~m}^{3} /\right.$ tree/year $)$ Meantime, $\mathrm{I}_{2}\left(8.25 \mathrm{~m}^{3} /\right.$ tree/year) gave similar effect like $\mathrm{I}_{3}$ on 


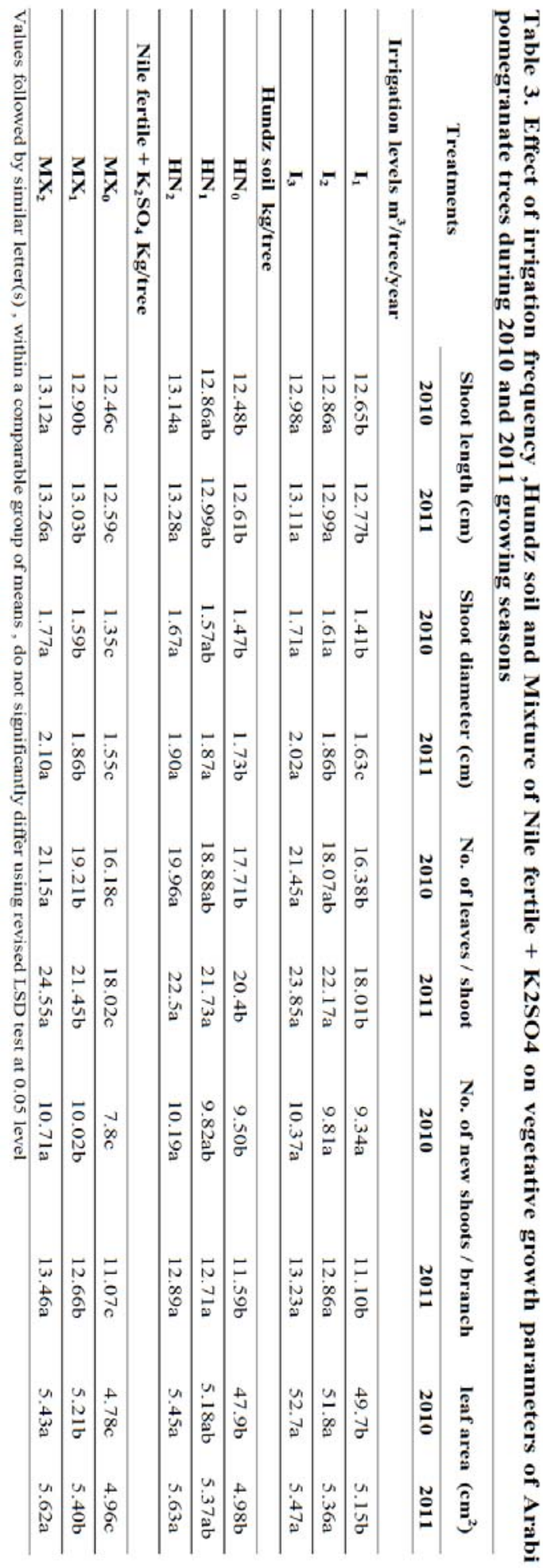


vegetative growth parameters except for shoot diameter in the second season. However, there was insignificant difference between different levels of irrigation on number of new shoots $/$ mainbranch in the $1^{\text {st }}$ season only.Generally, increasing irrigation levels enhanced vegetative growth of pomegranateby increasing shoot length, number of leaves per shoot and leaf area. It can be explained that water stress decreased the cytokinin transport from roots to shoots and increased the amount of leaf abscisic acid. These change in hormone balance caused a reduction in cell growth and leaf expansion. These results agree with those obtained by El-Iraqy et al., (2006) on guava and Khattab et al.,(2010)on pomegranate, as they stated that vegetative growth parameters were markedly increased by increasing irrigation rates.

With respect to the main effects of Hundz soil (soil conditioner) on vegetative growth parameters, the results in Table(3) showed that gradual increment of Hundz soil application up to $10 \mathrm{Kg}$ / tree resulted in a significantincreasesof vegetative growth, compared to control, in both seasons. The obtained resultssuggested generally that improvingthe morphological characters of pomegranate trees after application of Hundz soil may be due to increasecation exchange capacity and mineral nutrients, which in turn encouraged the plant growth. In this respect Kay-Shoemake et al.,(2000)found that application of soil conditioner (polyacrylamide PAM)increased the availability of nutrients, especially $\mathrm{N}$ via enhancing the activity of soil enzymes (urease and amidase), which involved in $\mathrm{N}$ cycling. Besides, the influence of PAM on reducing the leached amount of NH4 and NO3 (Bres and Weston, 1993), especially under the higher intervals of irrigation. Thus, the biosynthesis of proteins DNA and RNA would be enhanced leading to more initiation and division of the apical meristem cells; consequently, the plant height could be increased. Similar trend of results was found by Hoda -Khalil(2005) and Eman-Abd - Ella (2006).

As for theeffect of application of both Nilefertile $\mathrm{NF}+\mathrm{K}_{2} \mathrm{SO}_{4}$ on the vegetative growth characters, the results in Table (3) showedthat using different levels of Nilefertile $+\mathrm{K}_{2} \mathrm{SO}_{4}$ significant improving all the vegetative growth characters comparing to the control treatment in both seasons. The maximum values of shoot length, diameter, number of shoots per main branch, number of leaves / shoot and leaf areawere recorded on the trees receivedNilefertile $\left(\mathrm{NF}_{2}\right)$ at 2 $\mathrm{Kg} /$ tree $+\mathrm{K}_{2} \mathrm{SO}_{4}$ at $500 \mathrm{gm} /$ tree compared with those of either control or $\left(1 \mathrm{Kg} /\right.$ tree $\mathrm{NF}+250 \mathrm{gm} \mathrm{K}_{2} \mathrm{SO}_{4} /$ tree $)$ in the two seasons. The Stimulative effects of $\mathrm{K}_{2} \mathrm{SO}_{4}$ on growth parameters maybe due to that kis essential for the synthesis of amino acids, thus plants don't grow well in the absence of K (Edmond et al., 1975). Also, it is very important in the plant photosynthesis process and helping plants metabolize their food to get energy. It is involved in many aspects of plant physiology (Marschner, 1995). The positive effect ofNilefertile application on vegetative growth parameters may be due to it contains elemental sulfer (acidulous material) which is oxidized slowly to sulfuric acid after its application to soil. Also, it contains different SOxidizing bacteria so it reduced soil $\mathrm{pH}$ and increased nutrient availability. Moreover, sulfur is a part of every living cell and required for synthesis of certain amino acids. In this respectit is worthy to note that Abbas (1999), Sherin - Attia (2002) and Wael (2005) found that NF significantly enhanced vegetative growth of olive trees

\section{2-Leaf chemical composition}

Data in Table (4) illustrated the main effects of irrigation frequency, Hundz soil and mixture of Nilefertile $+\mathrm{K}_{2} \mathrm{SO}_{4}$ on leaf chemical composition i.e. leaf $\mathrm{N}, \mathrm{P}, \mathrm{K}$, total chlorophyll, proline and relative water content in both seasons.

The obtained results concerning the main effects of irrigation frequency revealed that, high irrigation level $\mathrm{I}_{3}\left(11 \mathrm{~m}^{3} /\right.$ tree/year $)$ as well as moderate level of irrigation $\mathrm{I}_{2}$ induced the highest leaf $\mathrm{N}, \mathrm{P}, \mathrm{K}$, total chlorophyll and relative water content in both seasons with one exception for $\mathrm{P}$ in the first one. The increase of leaf $\mathrm{N}, \mathrm{P}, \mathrm{K}$ content with increasing irrigation rate was previously reported by Hussein (2004) on pear, Chauhan et al.,(2005) on apple, and Khattab et al.,(2010) on pomegranate as they found that N, P, K contents were increased under the condition of high irrigation treatment. Reduction in leaf element contents with reducing irrigation amount is explained by a substantial decrease in transpiration rates and impaired active transport and membrane permeability, resulting in a reduced root absorbing power of nutrients.

Regarding leaf proline content, irrigation at 5.5 $\mathrm{m}^{3} /$ tree /year produced the highest proline content over other irrigation levelsin both seasons. Accumulation of proline amino acid in plant parts during water stress is important for absorption and might serve as a storage compound for reduced carbon and nitrogen during stress. El-said et al., (1993) and Hoda- Khalil (2005) on olive revealed that proline accumulation in olive leaves was affected by different water regimes.

Date in Table (4) showed the main effects of soil conditioner, Handz soil on leaf chemical components. Increasing Handz soil up to $10 \mathrm{Kg} /$ tree was associated with detected increments in leaf component except leaf 


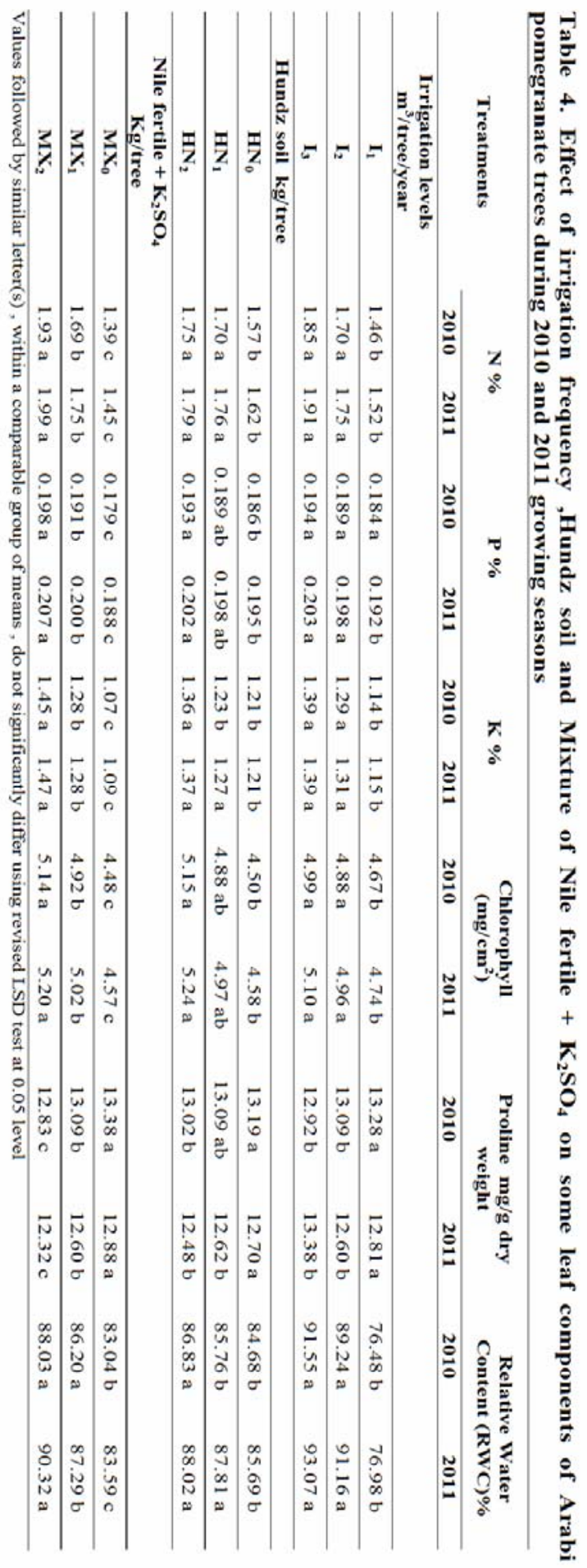


proline which showed an opposite trend.Application of Handz soil at rate of $10 \mathrm{Kg} /$ tree gave significantly higher mean values of $\mathrm{N}, \mathrm{P}, \mathrm{K}$, chlorophyll and (RWC) in both seasons. $\mathrm{HN}_{1}$ treatment gave similar trend of effect on leaf $\mathrm{N}$ inboth seasons as well as $\mathrm{K}$ and relative water content in the second one. Data also indicated that the untreated trees gave the maximum values of leaf proline in both seasons. These results may be due to that soil conditioner reduced the leached amounts of $\mathrm{N}$ as $\mathrm{NH}_{4}^{+}$and less as $\mathrm{NO}_{3}^{-}$, serves as a nitrogen source and improves the conditions of soil which enhanced the decomposition of organic matter (Wallace and Wallace, 1986) with increasing the activity of soil enzymes such as urease and amidase (Kay- Shoemake et al., 2000), thus $\mathrm{N}$ availability and translocation would be increased consequently the $\mathrm{N} \%$ in the leaves could be increased. Similar trend of results was stated by Silberbush et al., (1993) who reported that large amount of water absorbed by (PAM) soil conditions material (80\%-85\%) stored in vacuoles within its matrix. Diffusion of water into the soil solution would render water available to plant. Undoubtedly, increasing available soil moisture would ultimately increase nutrients absorption and translocation by plant.

Data in table (4)clearly indicated that increasing the rates of the mixture up to $2 \mathrm{Kg} /$ tree Nilefertile $+500 \mathrm{gm}$ /tree $\mathrm{K}_{2} \mathrm{SO}_{4}$ led to progressive significant increases in the value of leaf $\mathrm{N}, \mathrm{P}, \mathrm{K}$ and total chlorophyll in both seasons and relative water content in the second season, compared with the control. Similar trend was obtained on relative water content as a result of application of $1 \mathrm{Kg} /$ tree Nilefertile $+250 \mathrm{gm} /$ tree $\mathrm{K}_{2} \mathrm{SO}_{4}$ in the first season. In the meantime, leaf proline showed an opposite trend where control treatment gave the highest percentage than other treatments in both seasons. Gething (1986)reported that K supply to the plants affect nitrogen efficiency, but there is an evidence of a more direct connection between the two elements, that $\mathrm{K}$ ion acts as a carrier for nitrate from the root to the leaf, where proteins are synthesized. Also, $\mathrm{K}$ ion, being very mobile, promotes the uptake of the nitrate by the root. These results are similar to those of Mohammed and Mohammed (2010) on apples. Moreover,Abbas, (1999) reported that application of Nilefertile to soil increased olive leafN,P, $\mathrm{K}$ and chlorophyll and decreased proline content. Also, Wael (2005) found that olive leaf content of $\mathrm{N}, \mathrm{P}$ and $\mathrm{K}$ were increased by increasing levels of NF.

\section{3-Flowering, Fruiting and Yield}

The results of main effects of irrigation frequency, Hundz soil and mixture of Nilefertile $+\mathrm{K}_{2} \mathrm{SO}_{4}$ on number of flower/ shoot, fruit set percentage and yield are presented in Table (5). The obtained results indicated that the highest mean value of number of flowers /shoot, fruit set percentage and yield were associated with highest rate of irrigation level at $11 \mathrm{~m}^{3} /$ tree/year compared to $\mathrm{I}_{1}\left(5.5 \mathrm{~m}^{3} /\right.$ tree $/$ year $)$, in both seasons. In the meantime, $\mathrm{I}_{2}\left(8.25 \mathrm{~m}^{3} /\right.$ tree /day $)$ hada similar effect as $\mathrm{I}_{3}$ on this respect. No significant differences were found between $\mathrm{I}_{3}$ and $\mathrm{I}_{2}$ on fruit set percentage and yield in both seasons. Such results are in harmony with Hussein (2004) on pear and Khattab et al.,(2010) on pomegranate who found that, increasing the amount of applied water increased flower number per shoot, fruit setting and yield.

Concerning the main effects of Hundz soil onpreviously mentioned parameters, the results in Table (5) illustrated generally that application of Hundz soilat $10 \mathrm{Kg}$ /treereflectedsignificant increasing effects on the mean values of the previous characters than other treatments in both seasons. Hundz soil has ahigh cation exchange capacity and hence it willaffect soil nutritional capacity and the supply of nutrients to plants. Also, it has a high water absorbing capacity thus will affect positively the yield (Wafaa El-Etr, 2001) .These results are in correspondence with those obtained by Saddik and Laila -Ali et al., (2009) who found that the yield of peanut and carrot increased significantly by natural amendments application compared to nontreated one.

Regarding the application of Nilefertile $+\mathrm{K}_{2} \mathrm{SO}_{4}$ levels on no. of flowers /shoot, fruit set percentage and yield ( $\mathrm{Kg} /$ tree)the data in Table(5) indicated that the mean values of each studied character were high enough to be significant in both seasons. The results revealed that increasing mixture of Nilefertile and $\mathrm{K}_{2} \mathrm{SO}_{4}$ up to $2 \mathrm{~kg} /$ tree and $500 \mathrm{gm} /$ tree respectively $\left(\mathrm{MX}_{3}\right)$ gave maximum values ofthe studied characters. The superiority of the highest level of the mixture might be referred to application of $\mathrm{K}_{2} \mathrm{SO}_{4}$ which activates more enzyme systems, aids in photosynthesis, promote water uptake, regulates nutrients translocation in plant, favors carbohydrate transport and increases yield (Marschner, 1995). Similar results were obtained by ElIraqy et al., (2006), on guava and Mohammed and Mohammed (2010) on Apple.

The favorable influences of Nilefertile application on fruit set and yield could be related to the vital role of a mixture of ground rocks and minerals (45\%) in increasing the availability of nutrient supply, improving the efficiency of macro-elements as well as its ability to meet some micro-elements requirements of crop, which in turn, should be reflected on production of high yield. Furthermore, NF contains elemental sulfer (32\%) which is oxidized slowly to sulfuric acid, after its application to soil, below the drip lines, that prevented salt 


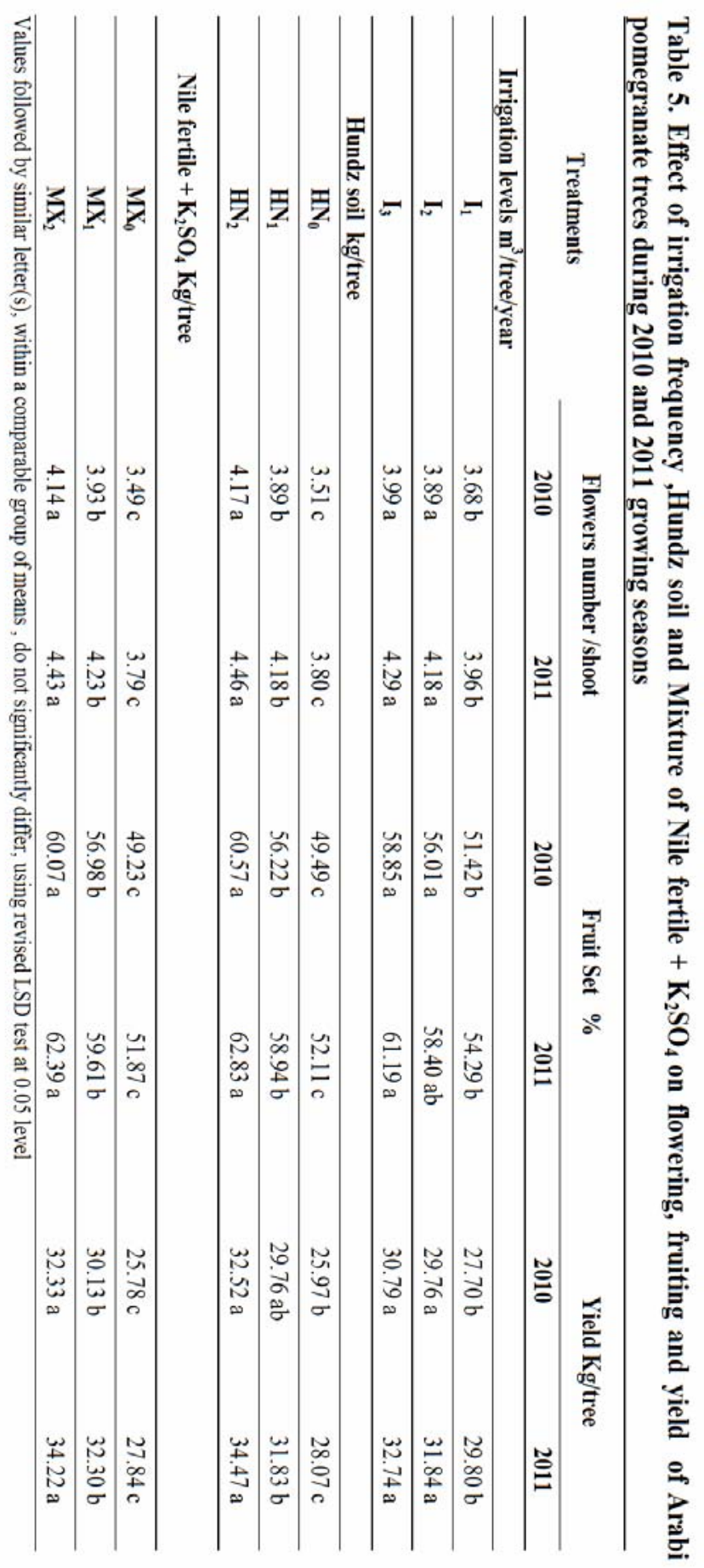


accumulation around the roots and sustained the yield.The results are in line with those of Wael (2005) who found that increasing level of NF significantly enhanced olive fruit set and yield.

\section{4-Fruit Physical Properties}

Effect of irrigation levels on fruit weight, dimensions and fruit size are illustrated in Table (6). Fruit physical properties gradually increased with increasing irrigation levels in both seasons.Data also indicated that moderate irrigation level $\left(\mathrm{I}_{2}\right)$ enhanced fruit physical properties like high irrigation level $\mathrm{I}_{3}$ however the differences between two irrigation were not big enough to be signification. These resultsare in line with those obtained by Kandil and El-Feky (2006) on apricot and Khattab et al., (2010) on pomegranate as they concluded that fruit physical properties were improved when subjected to the highest irrigation rate.

Data in Table (6) showed that the highest fruit weight, length and diameter were obtained by application of $10 \mathrm{Kg}$ /tree Hundz soil. Significant differences were found between $\left(\mathrm{HN}_{2}\right)$ the highest level and the control $\left(\mathrm{HN}_{0}\right)$ on fruit physical characteristics in both seasons. Fitzpatrick, (1986) found that Humus (soil conditioners) is capable to absorb large quantities of water; thus increasing the water holding capacity of the soil and therefore crop production.

As for the main effect of application of mixture of Nilefertile $+\mathrm{K}_{2} \mathrm{SO}_{4}$ the data in table (6) indicated that the highest fruit weight length and diameter were obtained by the addition of $2 \mathrm{Kg} \mathrm{NF}+500 \mathrm{gm} \mathrm{K}_{2} \mathrm{SO}_{4}$ $\left(\mathrm{MX}_{3}\right)$. On the other hand, the least significant values of the fruit physical properties were obtained by the lowest level of the fertilizer mixture $\left(\mathrm{MX}_{0}\right)$. No significant differences were found between high level of (NF + $\left.\mathrm{K}_{2} \mathrm{SO}_{4}\right)$ and the moderate level of $\left(\mathrm{Mx}_{2}\right)$ on fruit length in $2^{\text {nd }}$ season and diameter in the $1^{\text {st }}$ one. These results are coincided with El-Iraqy etal.,(2006) on guava and Mohammed and Mohammed (2010) on apples as they found that fruit weight and dimensions increased by increasing $\mathrm{K}$ levels.

\section{5-Fruit Chemical Composition:}

The main effects of different irrigation frequency levels on fruit chemical composition, (total soluble solids, anthocyanin, V.C., acidity and tannins are shown in Table (7).

Data clarified the presence of significant increment in fruit juice total soluble solids, anthocyanin and V.C. as a result of increasing irrigation frequency levels. High irrigation level $\mathrm{I}_{3}\left(11 \mathrm{~m}^{3} /\right.$ tree /year) recorded the highest values of fruit juice anthocyanin in seasons as well as TSS and V.C in the second one. Irrigation level of $8.25 \mathrm{~m}^{3} /$ tree /year behaved the same analogous effect on the previous fruit characteristics. However, in the first season, no significant differences were found between irrigation levels on TSS and V.C. High irrigation level $(11 \mathrm{~m} 3 /$ tree /year $)$ decreased significantly acidity and tannins content of pomegranate fruit compared to the rest of treatments during both seasons. The results are in line with those obtained by Lawand and Patil (1996) and Khattab et al., (2010) on pomegranates; they stated that the highest fruit acidity was observed with the lowest irrigation level. Also, ElKhoreiby and Salem (1989) and El-Iraqy et al., (2006) indicated that increasing soil moisture content increased V.C. content as well as decreased tannins content of guava . On the contrary, Khattab et al.,(2010) found that anthocyanin content decreased by increasing irrigation levels in pomegranate juice.

Concerning the main effects of application of Hundz soil on fruit chemical composition, the results reflected that Hundz soil at highest rate $(10 \mathrm{Kg} /$ tree $)$ increased fruit juice TSS and anthocyanin in both seasons. However this trend of increment did not reach the significance level for V.C in the $2^{\text {nd }}$ season. Fruit acidity and tannins were significantly decreased as application ofHundz soil increased. Addition high rate of Hundz soil $(10 \mathrm{Kg} /$ tree $)$ significantly gave the lowest percent than either of treatment $\mathrm{HN}_{0}$ or $\mathrm{HN}_{1}$ in both seasons.

The results of the main effects of Nilefertile + $\mathrm{K}_{2} \mathrm{SO}_{4}$ levels on fruit chemical composition i.e. TSS, anthocyanin and V.C illustrated generally that the comparisons among the mean values of each studied character were high enough to be significant, in both seasons except TSS in the $1^{\text {st }}$ season which reflected no significant differences between $\mathrm{MX}_{2}$ and $\mathrm{MX}_{1}$. The results showed also that the application of $2 \mathrm{Kg} /$ tree Nilefertile $+500 \mathrm{gm} /$ tree $\mathrm{K}_{2} \mathrm{SO}_{4}$ was most favorable treatment that gave significant highest mean values of the previous characteristicsin both seasons. However, fruit acidity and tannins content were significantly decreased by application of high rate of Nilefertile and $\mathrm{K}_{2} \mathrm{SO}_{4}$ in both seasons. The results are in harmony with El-Iraqyet al.,(2006) on guava and Mohamed and Mohamed (2010) on apple. They found that K fertilization positively affected fruit chemical composition.

\section{2-First-order interactions effects}

\subsection{Vegetative growth}

Results in Table (8) illustrated the effects of the first-order interactions (Irrigation levels $\times$ Hundz soil, Irrigation levels $\times$ mixture from (Nilefertile $+\mathrm{K}_{2} \mathrm{SO}_{4}$ ) 


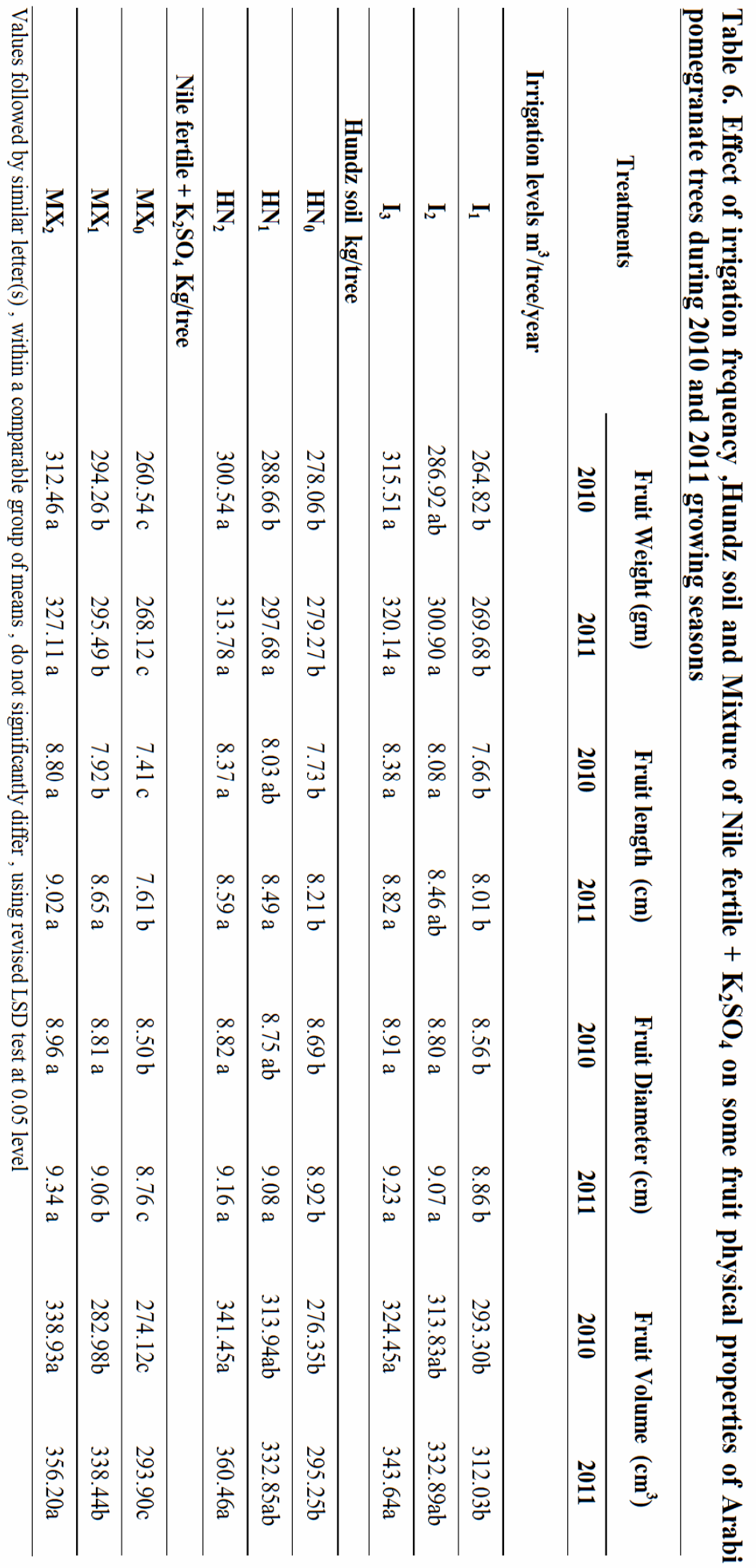




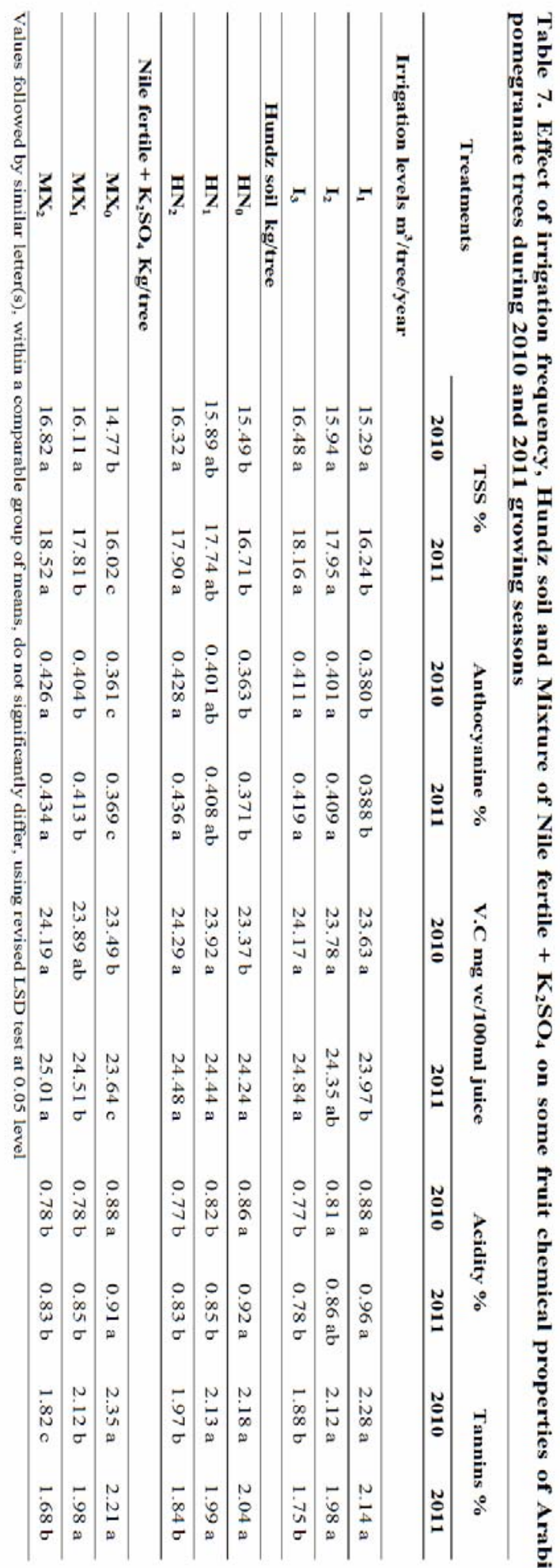




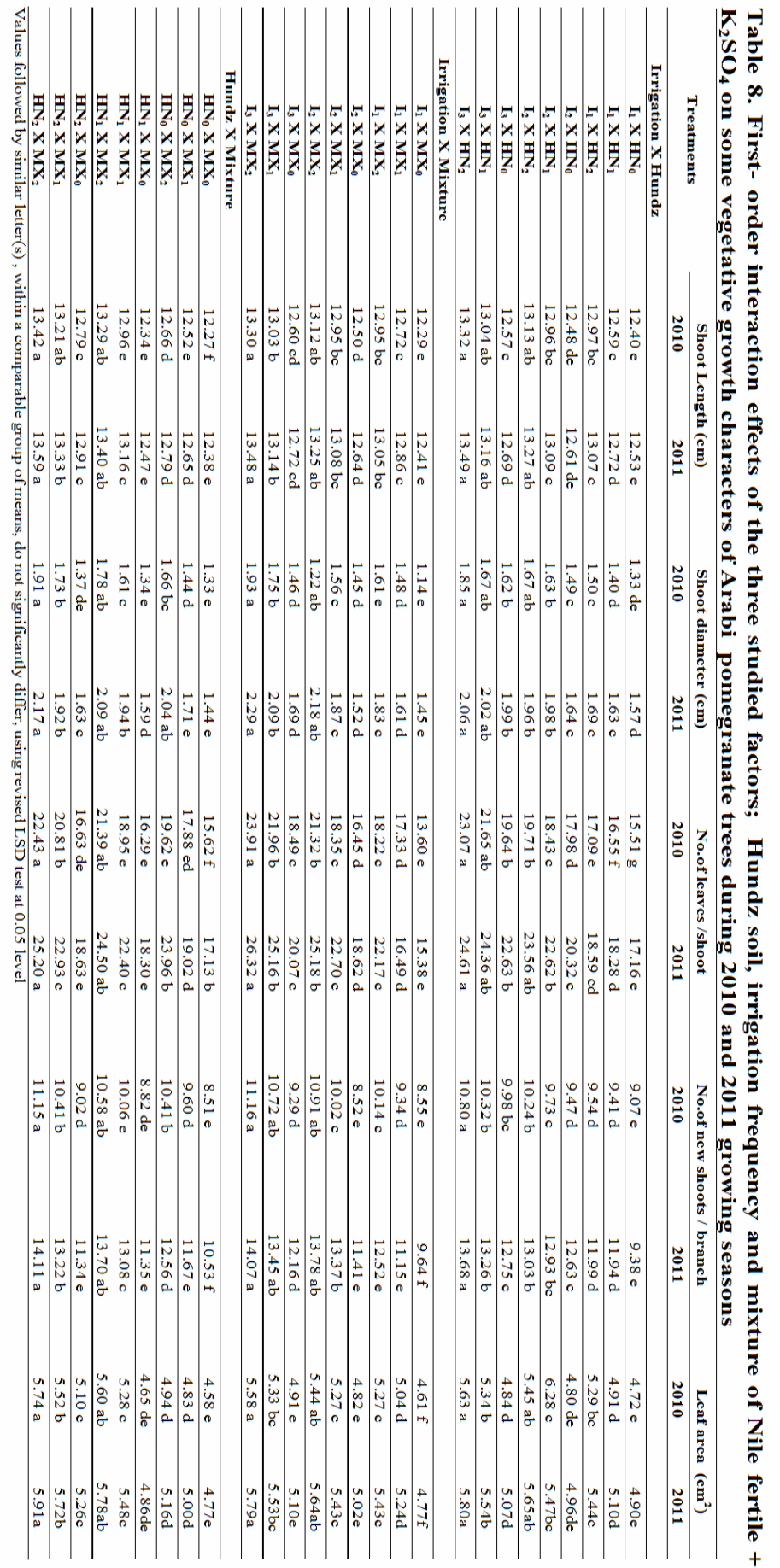


and Hundz soil $\times\left(\right.$ Nilefertile $\left.+\mathrm{K}_{2} \mathrm{SO}_{4}\right)$ on vegetative growth characters of Arabi pomegranate trees.

The effects of interactions between irrigation levels and Hundz soil on the characters of shoot length, diameter, number of leaves/ shoot as well as number of shoots/ main branch and leaf area were found to be significant in both seasons when compared with control treatment of any level of irrigation. The combination between high irrigation level $11 \mathrm{~m}^{3}$ /tree/ year and Hundz soil at high rate $10 \mathrm{Kg} /$ tree $\left(\mathrm{I}_{3} \times \mathrm{HN}_{2}\right)$ reflected the best interaction, which gave significantly the highest mean values of all vegetative growth characters in both seasons followed by the application of highest rate of Hundz soil $(10 \mathrm{Kg} /$ tree $)$ combined with the second level of irrigation frequency $8.25 \mathrm{~m}^{3} /$ tree /year $\left(\mathrm{I}_{2} \times\right.$ $\mathrm{HN}_{2}$ )which gave higher significant mean values for all the studied vegetative growth parameterscomparied with $100 \%$ of the recommended irrigation level $\left(\mathrm{I}_{3} \times\right.$ HNO) in both seasons. Similar results were obtained with Hundz soil application at rate of $5 \mathrm{Kg} /$ tree in combination with irrigation level $8.25 \mathrm{~m}^{3} /$ tree/year $\left(\mathrm{I}_{2} \times\right.$ $\mathrm{HN}_{1}$ ) in all parameters with exceptions, for number of leaves /shoot and number of new shoots /branch in the $1^{\text {st }}$ season. On the other hand, the least vegetative growth characters were obtained when pomegranate trees irrigated with lowest irrigation level $\left(\mathrm{I}_{1} \times \mathrm{HN}_{0}\right)$ in both seasons. Such results might be contributed to increase available water holding capacity hydraulic conductivity and water diffusivity of sandy soil due to the application of soil conditioner which reflected to the plant growth (Im, 1982).

The interaction effects between irrigation levels and mixture from Nile fertile $+\mathrm{K}_{2} \mathrm{SO}_{4}$ treatments are presented in Table (8). The results reflected generally that the application of high rate mixture $(2 \mathrm{Kg}+500 \mathrm{gm}$ $\left.\mathrm{K}_{2} \mathrm{SO}_{4}\right)$ combined with higher irrigation level $\left(11 \mathrm{~m}^{3}\right.$ /tree /year) was favorable for the plant trees to express their performance on all vegetative growth characters. Data also indicated that the combination between second irrigation level $\left(\mathrm{I}_{2}\right)$ with either application of the mixture at high or low rate $\left(\mathrm{I}_{2} \times \mathrm{MX}_{1}\right.$ orMX $\left.\mathrm{M}_{2}\right)$ had similar trend of effects on vegetative growth characters like trees which irrigated with $11 \mathrm{~m}^{3} /$ tree/year without Nilefertile $+\mathrm{K}_{2} \mathrm{SO}_{4}\left(\mathrm{I}_{3} \times \mathrm{MX}_{0}\right)$ with one exception for no.of leaves/shoot in the1st season. Reversely, the least level of irrigation combined with the least rate of mixture of Nile fertile $+\mathrm{K}_{2} \mathrm{SO}_{4}\left(\mathrm{I}_{1} \times \mathrm{MX}_{0}\right)$ decreased significantly all vegetative growth parameters. This may be due to that $\mathrm{K}$ nutrition maintains high tissue water content under shortage of water (lindhauer, 1985). These data are coincided with El-Iraqy et al., (2006) on guava.
Regarding the interaction effects between Hundz soil and Nile fertile $+\mathrm{K}_{2} \mathrm{SO}_{4}$ mixture on vegetative growth characters, the results in Table (8) reflected generally that the comparisons among the mean values for the vegetative growth characters are affected by these factors appeared to be significant in both seasons. The obtained results illustrated that Hundz soil application at rate of $10 \mathrm{~kg} /$ tree combined with Nile fertile $+\mathrm{K}_{2} \mathrm{SO}_{4}$ at higher rate reflected the best interaction treatment since it gave the highest mean values for all the studied vegetative growth characters in both seasons. Theseresults reflected partial agreement with those obtained by Wallace and Wallace (1986)who found that applying soil conditioner (PAM) to organic source gave additive effect on growth of tomato and wheat plants and increasing water holding capacity of PAM treated soil reducing the frequency and total amount of irrigation required for several crops. Similarly Abbas (1999)found that using sulfer fertilizer mixture (Nilefertile) increased some growth parameter of olive seedlings due to it prevent salt accumulation around the roots and sustained the growth and yield of cucumber and onion (Badr, 1992).

\subsection{Leaf chemical composition}

Data in Table (9) indicated the first order interaction effects between irrigation levels $\times$ Hundz soil, irrigation levels $\times$ mixture from Nile fertile $+\mathrm{K}_{2} \mathrm{SO}_{4}$ and Hundz soil $\times$ mixture of Nile fertile on leaf chemical composition; i.e. N, P, K, Chlorophyll, proline and relative water content in both seasons.

Concerning the interaction effects between irrigation levels and Hundz soil rates, data indicated that values of leaf N, P, K, chlorophyll and RWC for the combination between highest levels of Hundz soil with highest level irrigation $\left(\mathrm{I}_{3} \times \mathrm{HN}_{2}\right)$ were significantly higher than those of all other treatment combinations in both seasons. Whereas, leaf proline showed opposite trend, the date also indicated that combination treatment between $8.25 \mathrm{~m}^{3} /$ tree /year and $\mathrm{HZ}$ soil at highest rate $\left(\mathrm{I}_{2} \times \mathrm{HN}_{2}\right)$ gave the same characteristics results when compared with $100 \%$ of the recommended irrigation level $\left(\mathrm{I}_{3} \mathrm{x} \times\right.$ $\mathrm{HN}_{0}$ ) in both seasons. These results are in line with those of Hoda- Khalil (2005) who found that application of soil conditioner (PAM) increased leaf $\mathrm{N}$, $\mathrm{P}, \mathrm{K}$ and chlorophyll as well as decreased proline content of olive seedling.

Regarding the interaction effects between irrigation levels and mixture of (Nile fertile $+\mathrm{K}_{2} \mathrm{SO}_{4}$ ) on leaf chemical composition, the obtained results indicated that the treatment combination between highest irrigation level combined with the application of Nile fertile $+\mathrm{K}_{2} \mathrm{SO}_{4}$ at highest rate $\left(\mathrm{I}_{3} \times \mathrm{MX}_{2}\right)$ gave the highest values 


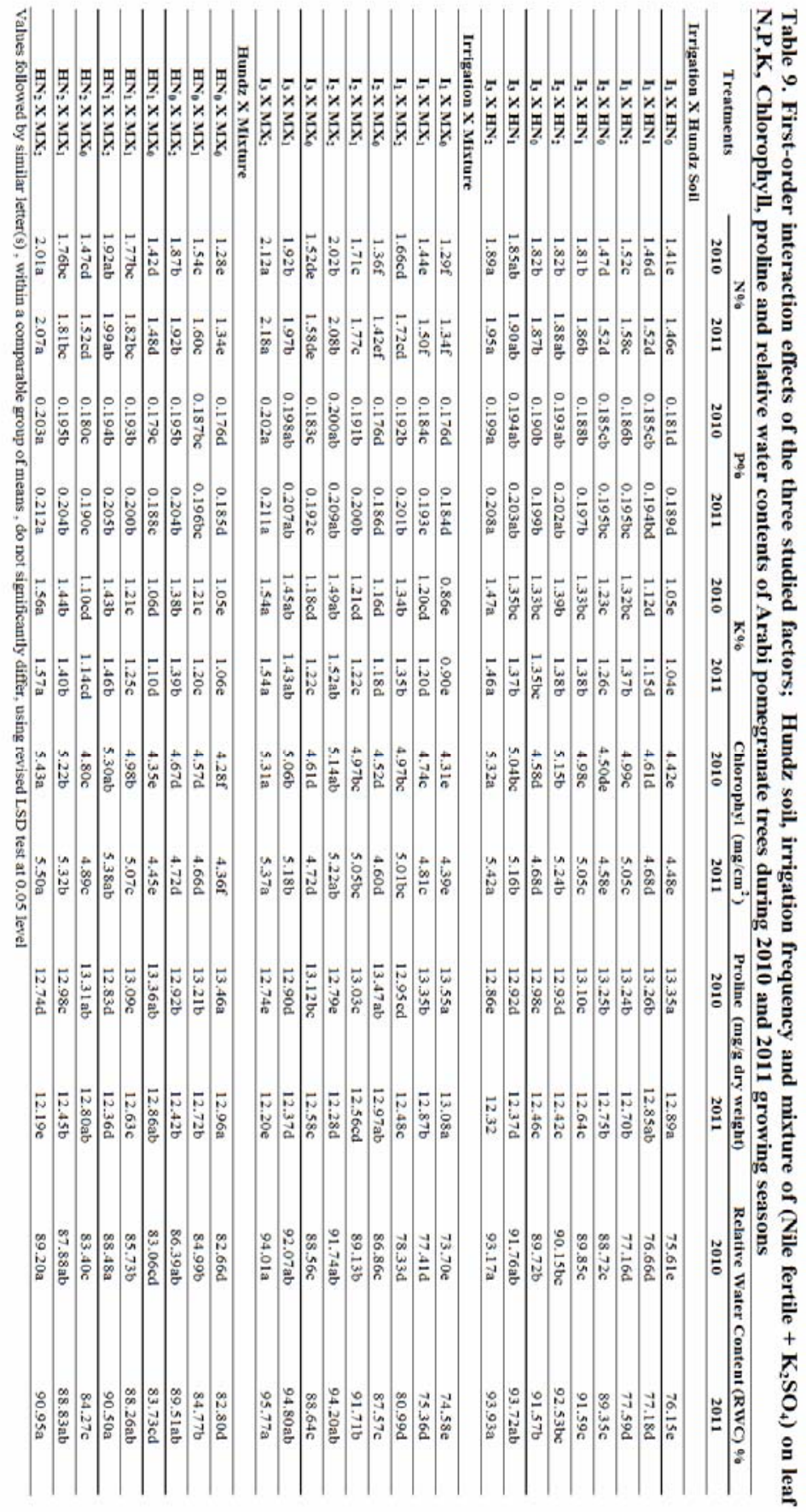


of all the studied leaf chemical composition, except leaf proline which showed opposite trend in both seasons. On the contrary, the lowest values between the previously mentioned interaction treatments were found with trees irrigated with $50 \%$ of the recommended irrigation level solely. In the meantime, irrigation trees with $8.25 \mathrm{~m}^{3}$ /tree /year combined with application of Nile fertile $+\mathrm{K}_{2} \mathrm{SO}_{4}$ at both higher rates $\left(\mathrm{MX}_{1}\right)$ or $\left(\mathrm{MX}_{2}\right)$ gave best results as compared with $100 \%$ of the recommend level of irrigation $11 \mathrm{~m}^{3} /$ tree /year $\left(\mathrm{I}_{3} \times\right.$ $\mathrm{MX}_{0}$ ) in both seasons.

Regarding the interaction effects, between the different rates of Hundz soil and the mixture of (Nile fertile $+\mathrm{K}_{2} \mathrm{SO}_{4}$ ) on leaf chemical components are represented in Table (9), the application of Hundz soil at the highest rate $10 \mathrm{Kg} /$ tree combined with the highest level from the mixture $(2 \mathrm{Kg}+500 \mathrm{gm} /$ tree $)$ caused a significant increase in leaf $\mathrm{N}, \mathrm{P}, \mathrm{K}$, chlorophyll and RWC as well as decreased leaf proline as compared with other treatments in both seasons. Meantime, application of the above combination treatments enhanced leaf components as compared with treatments which contain HN soil alone or treatment without any additions $\left(\mathrm{HN}_{0} \times \mathrm{F}_{0}\right)$ in both seasons, these results may be due to the additive effect between soil conditioners which increase water holding capacity, enhance nutrient efficiency and encourage soil microflora in sandy soils (Azzamet al., 1987). Also Hilal et al., (1997) reported that application of sulfur fertilizer mixture (SFM) to the salinity soil led to reduce soil $\mathrm{pH}$ and provide oxidizing conditions for the benefit of plant roots development, with corresponding improvement of water and nutrient utilization. While, Abbas (1999) found that using (SFM) increased leaf $\mathrm{N}, \mathrm{P}, \mathrm{K}$ and chlorophyll and decreasedproline of olive. Moreover,Wael (2005) found that increasing level of $\mathrm{K}$ and $\mathrm{NF}$ enhanced leaf minerals content of olive trees.

\subsection{Flowering, Fruiting and Yield}

The First order interaction effects among the irrigation levels, Hundz soil and mixture from (Nile fertile and $\mathrm{K}_{2} \mathrm{SO}_{4}$ ) on number of flowers /shoot, fruit setpercentage and yield of pomegranate trees are presented in Table (10).

As for the effects between Hundz soil and irrigation levels, the results indicated that the application of the highest rate of Hundz soil $10 \mathrm{Kg} /$ tree combined with high irrigation level $\left(11 \mathrm{~m}^{3} /\right.$ tree /year $)$ gave the most favorable interaction effect $\left(\mathrm{I}_{3} \times \mathrm{HN}_{2}\right)$, which showed the significant highest mean values for all the above studied parameter in both seasons. Similar, interaction effect was found between $\mathrm{HN}$ soil at both rates combined with either mediumor lower irrigation level $8.25 \mathrm{~m}^{3}$ or $5.5 \mathrm{~m}^{3} /$ tree /year on number of flower /shoot, fruit set $\%$ and yield when compared with trees irrigated with control treatment $11 \mathrm{~m}^{3} /$ tree /year only $\left(\mathrm{I}_{3} \times \mathrm{HN}_{0}\right)$ with one exception for fruit set \%with treatment $\left(\mathrm{I}_{1} \times\right.$ $\mathrm{HN}_{1}$ ) in both seasons. On the other hand, $5.5 \mathrm{~m}^{3}$ /tree /year level of irrigation without Hundz soil presented the lowest values of the previous mentioned characters in both seasons. The results are in line with Fitzpatrick, (1986) who found that application of Humus is capable of absorbing large quanties of water; thus increasing the water holding capacity of the soil and therefore crop production.

The effects of interactions between irrigation levels and different rates of Nile fertile $+\mathrm{K}_{2} \mathrm{SO}_{4}$ rates on the number of flowers /shoot, fruit set $\%$ and yield of pomegranate trees were found to be significant in the two seasons, as shown in Table (10). The highest level of irrigation combined with the mixture at higher rate $\left(\mathrm{I}_{3} \times \mathrm{MX}_{2}\right)$ showed the highest values of no. of flower /shoot, fruit set $\%$ and yield, whereas, the control of the lowest irrigation level without $\mathrm{NF}$ or $\mathrm{K}_{2} \mathrm{SO}_{4}\left(\mathrm{I}_{1} \times \mathrm{MX}_{0}\right)$ exhibited the least values in both seasons. In the meantime, combination between both levels of the mixture with $8.25 \mathrm{~m}^{3} /$ tree/year level $\left(\mathrm{I}_{2}\right)$ or $5.5 \mathrm{~m}^{3} /$ tree/year $\left(\mathrm{I}_{1}\right)$ gave almost the same effect on the above characters when compared with the control of the recommended irrigationlevel $\left(\mathrm{I}_{3} \times \mathrm{MX}_{0}\right)$ with one exception for fruit set percent. Such results generally reflected agreement with those reported by El-Iraqy etal., (2006) on guavaand Khattab et al., (2010) on pomegranate. Theyfound that highest numbers of flowers / shoot were obtained when trees received high rate of $\mathrm{K}$ combined with high level of irrigation. Furthermore, Badr (1992) found that mixing sulfur fertilizer mixture (Nile fertile) below the drip lines prevented salt accumulation around the roots and sustained the yield of both cucumber and onion.

As related to the interaction effect between Hundz soil and Nilefertile $+\mathrm{K}_{2} \mathrm{SO}_{4}$, results in Table (10) indicated that application of $10 \mathrm{Kg}$ /tree Hundz soil combined with $2 \mathrm{Kg} \mathrm{NF}+500 \mathrm{gm} \mathrm{K}_{2} \mathrm{SO}_{4}\left(\mathrm{HN}_{2} \times \mathrm{MX}_{2}\right)$ was favorable for plants to express their best performance on no. of flower /shoot, fruit set and yield as compared with others treatments in both seasons. Data also indicated that higher concentration of Hundz soil combined with lower rate of Nile fertile $+\mathrm{K}_{2} \mathrm{SO}_{4}\left(\mathrm{HN}_{2} \times \mathrm{MX}_{1}\right)$ gave similar trend of effect like combination between higher rate of mixture and lower rate of $\mathrm{HZ}_{1}\left(\mathrm{HZ}_{1} \times \mathrm{MX}_{2}\right)$ on the above characters in both seasons. The results are in line with Wael (2005) who found that fruit set and yield of olive trees enhanced with application of NF Whereas, Laila - Ali et al., (2009) who found that the combination treatment between organic and inorganic conditioners increased wheat yield. 


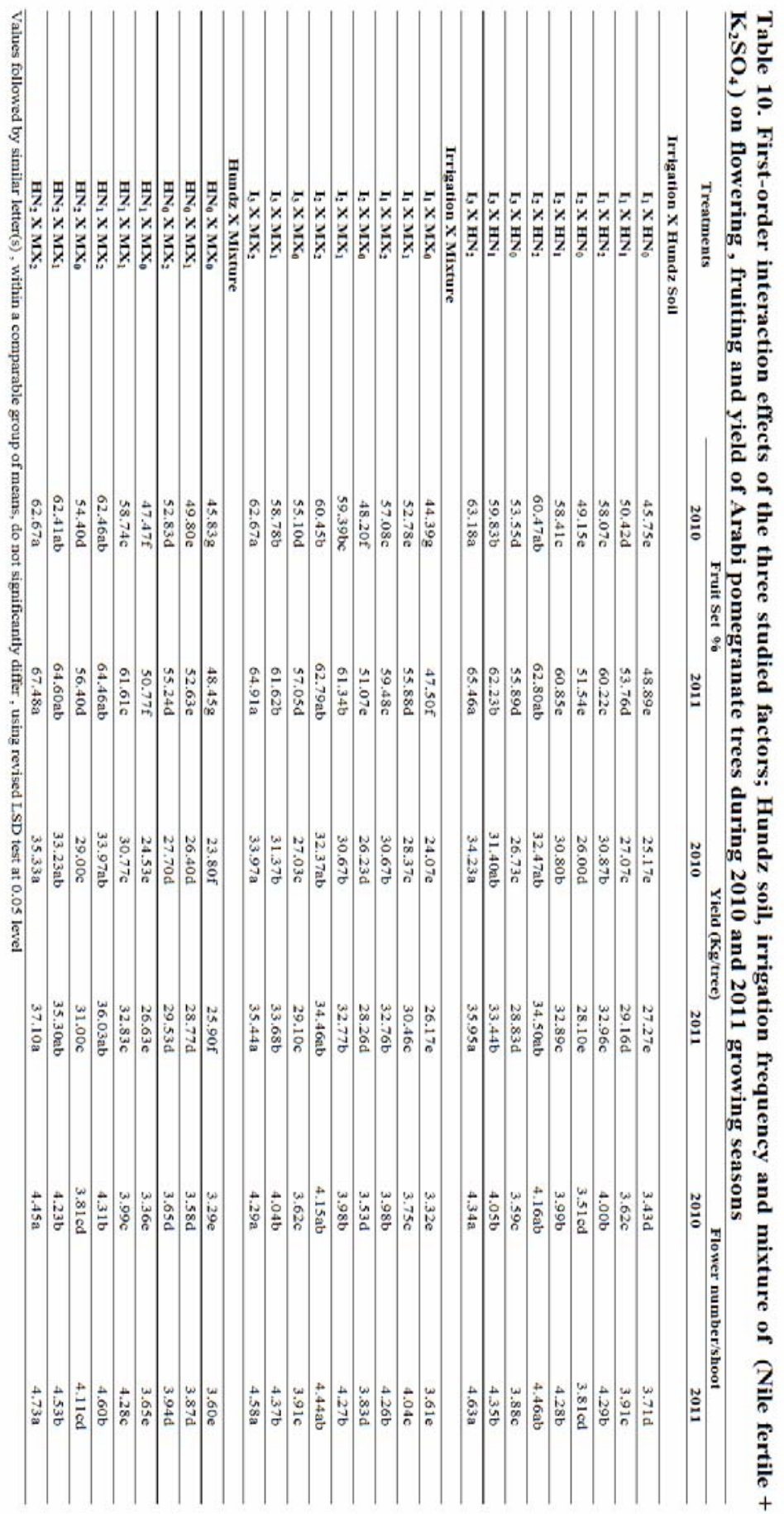




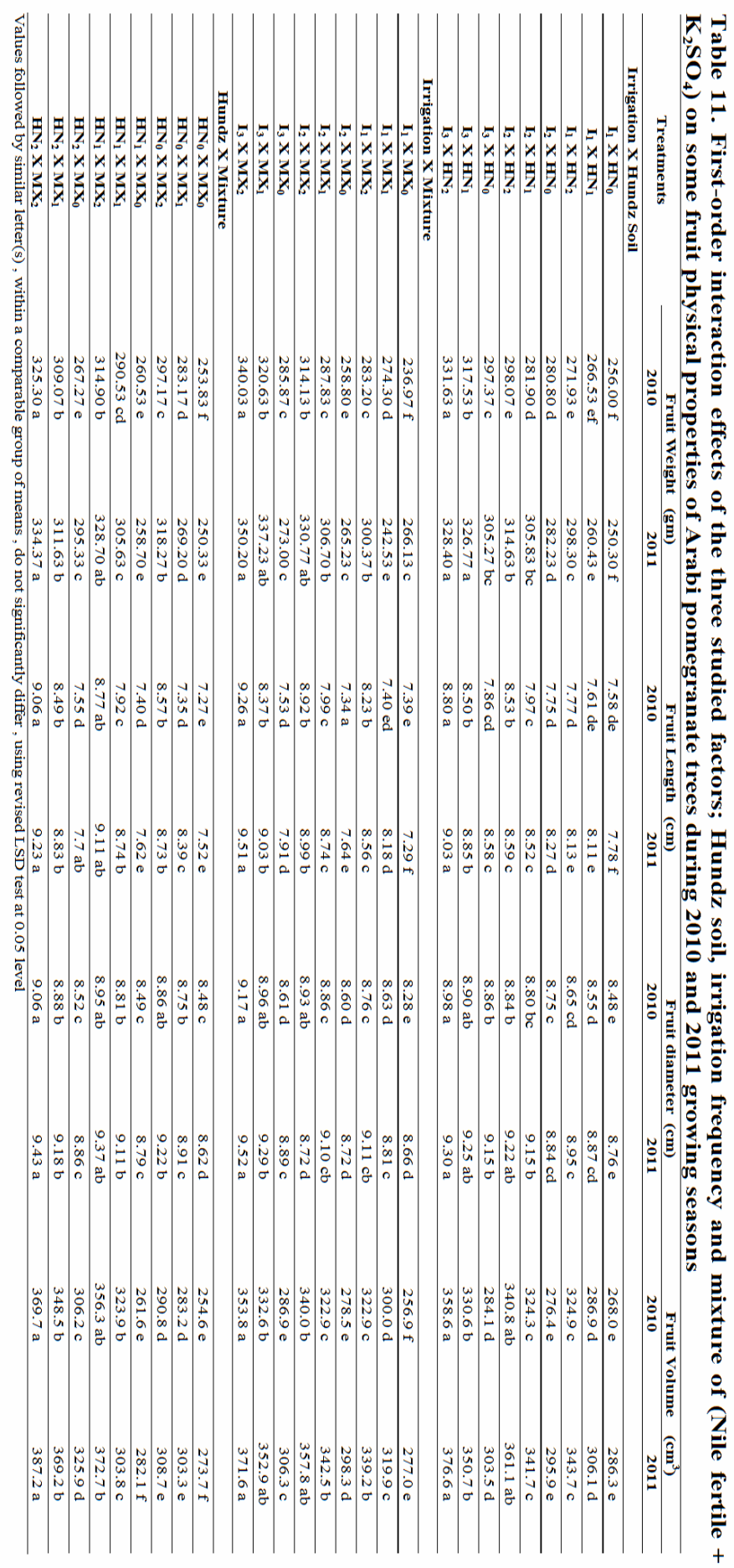




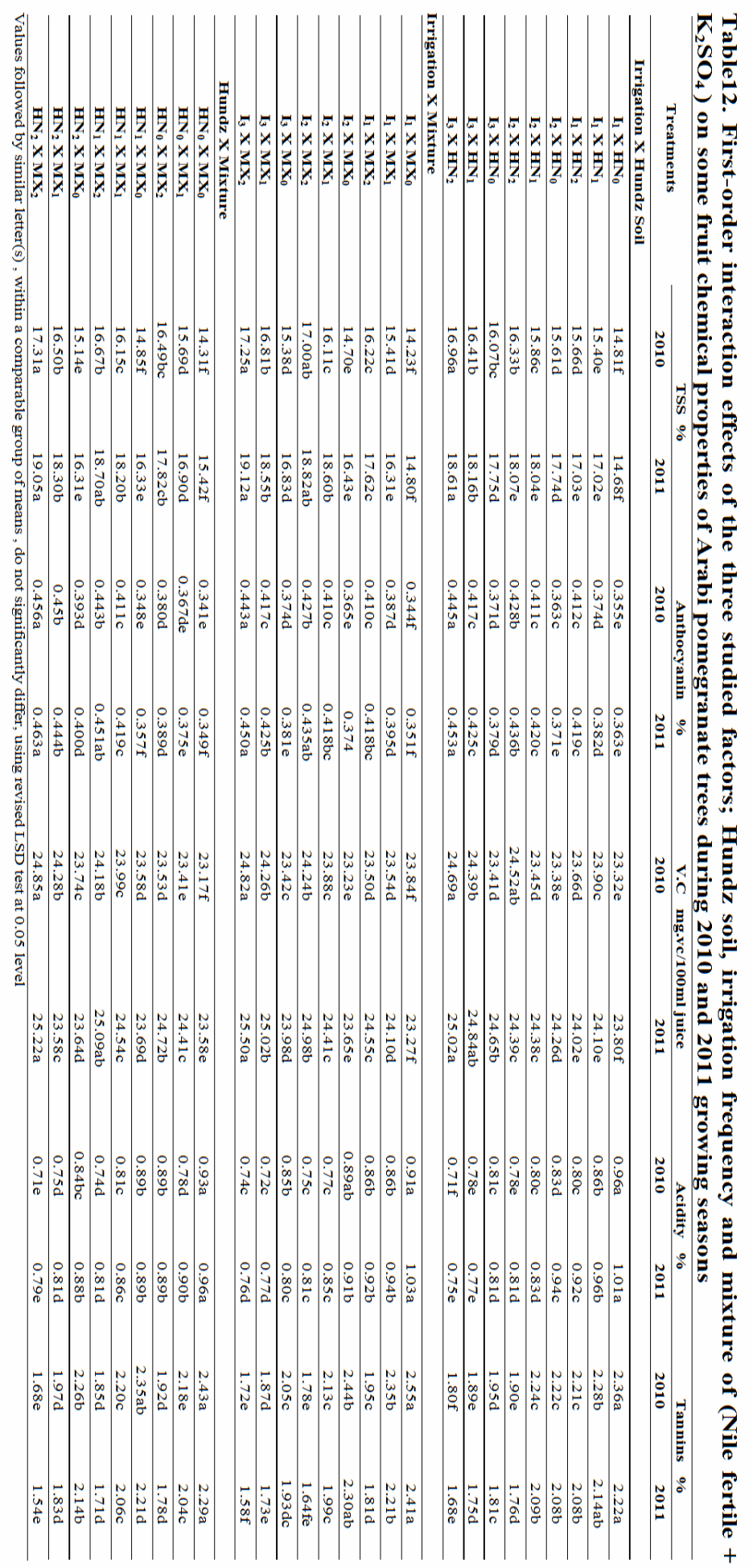




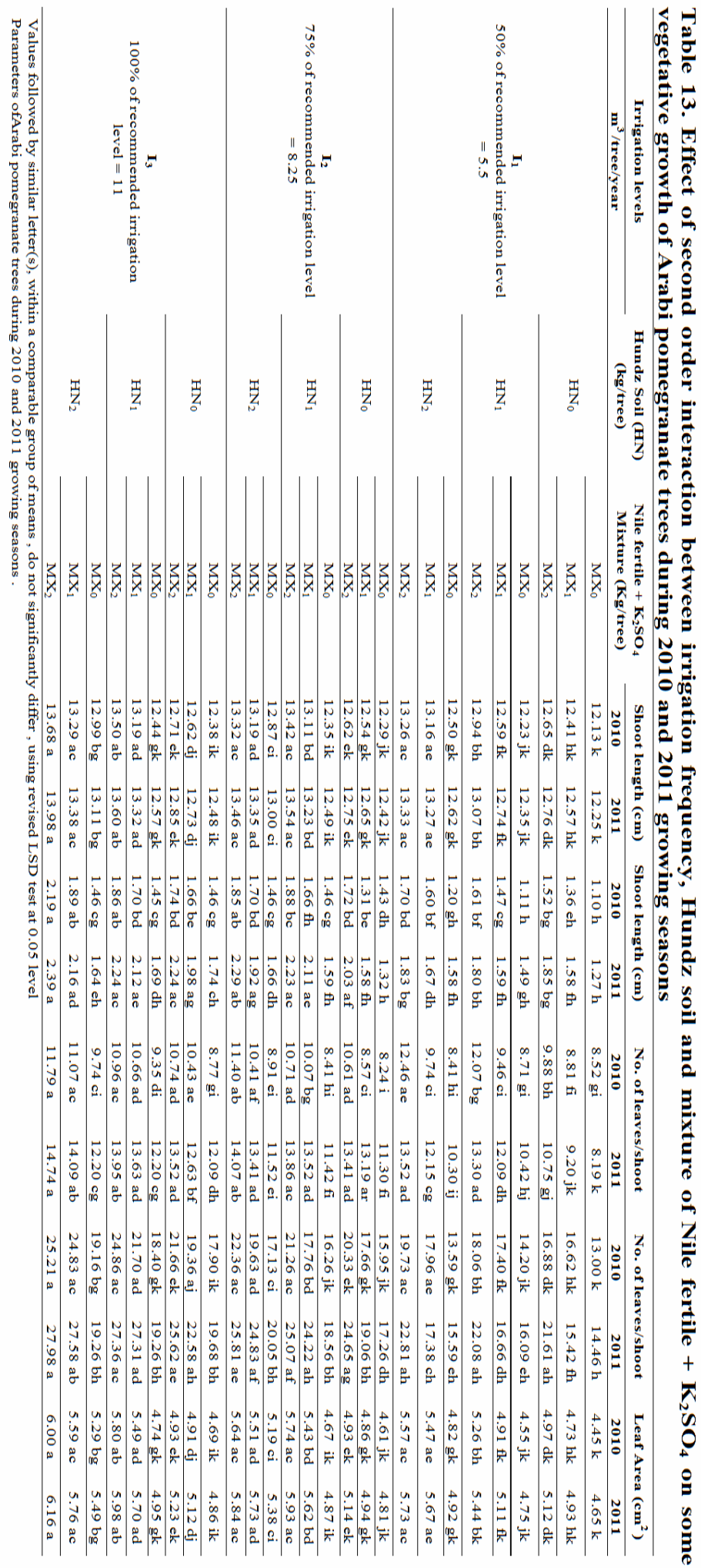




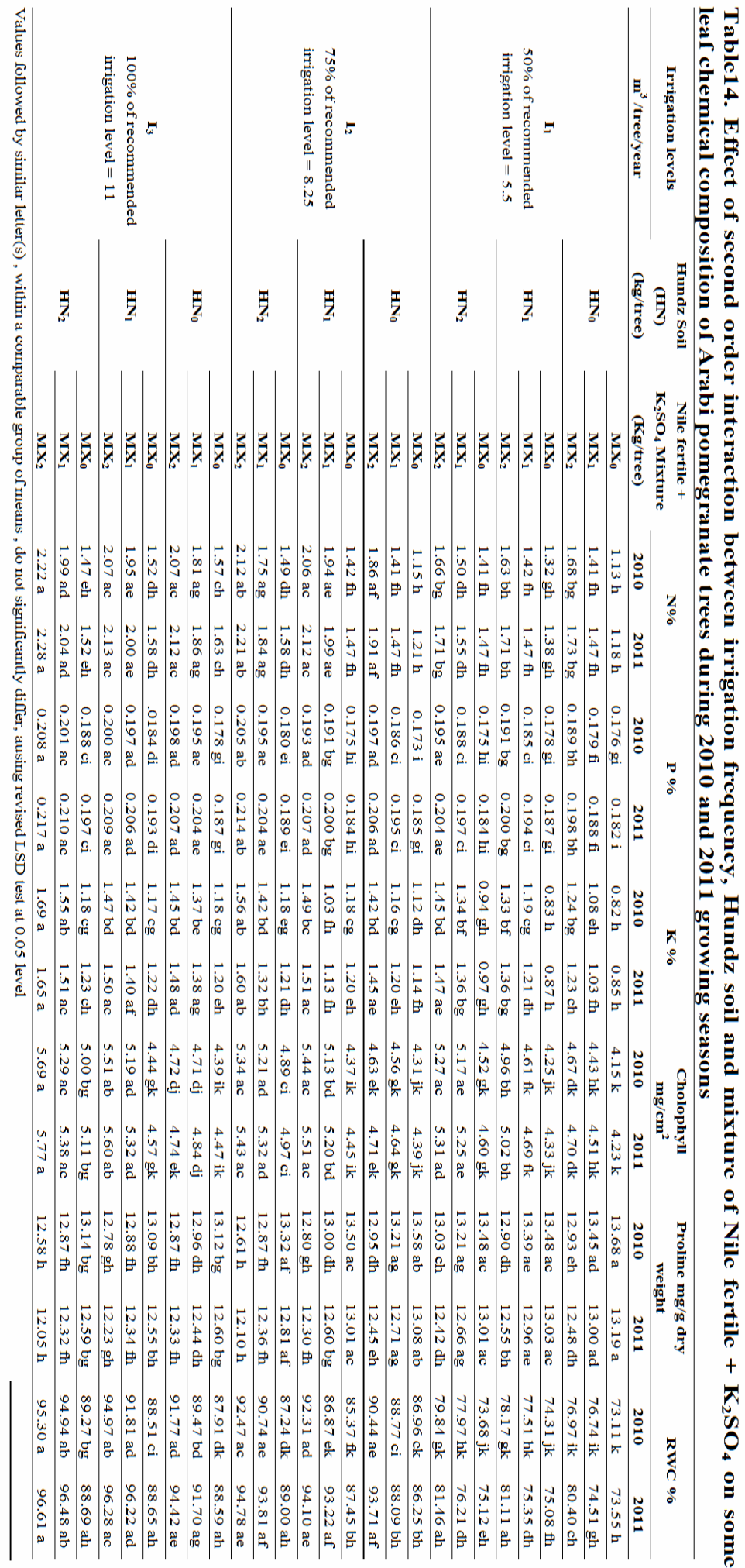




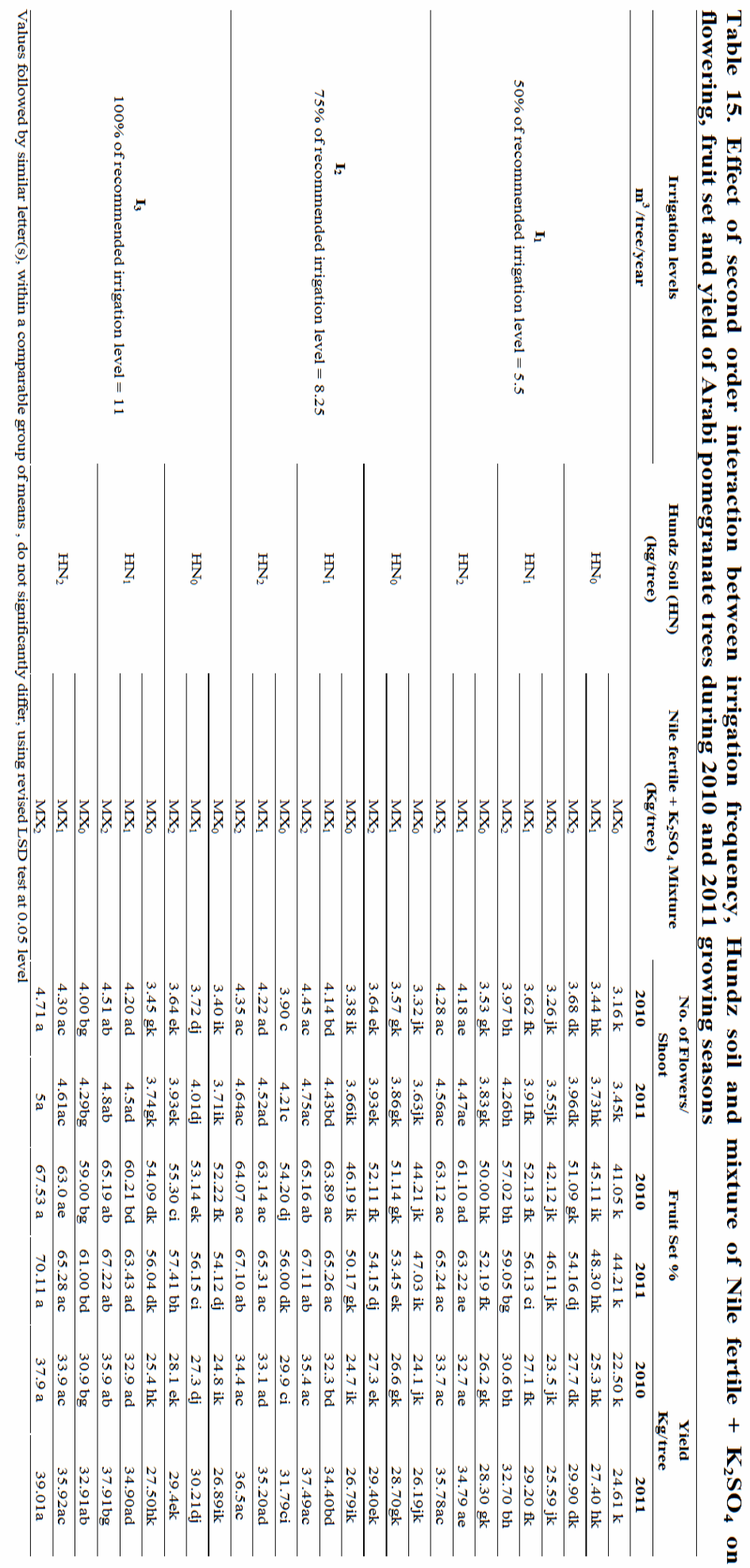




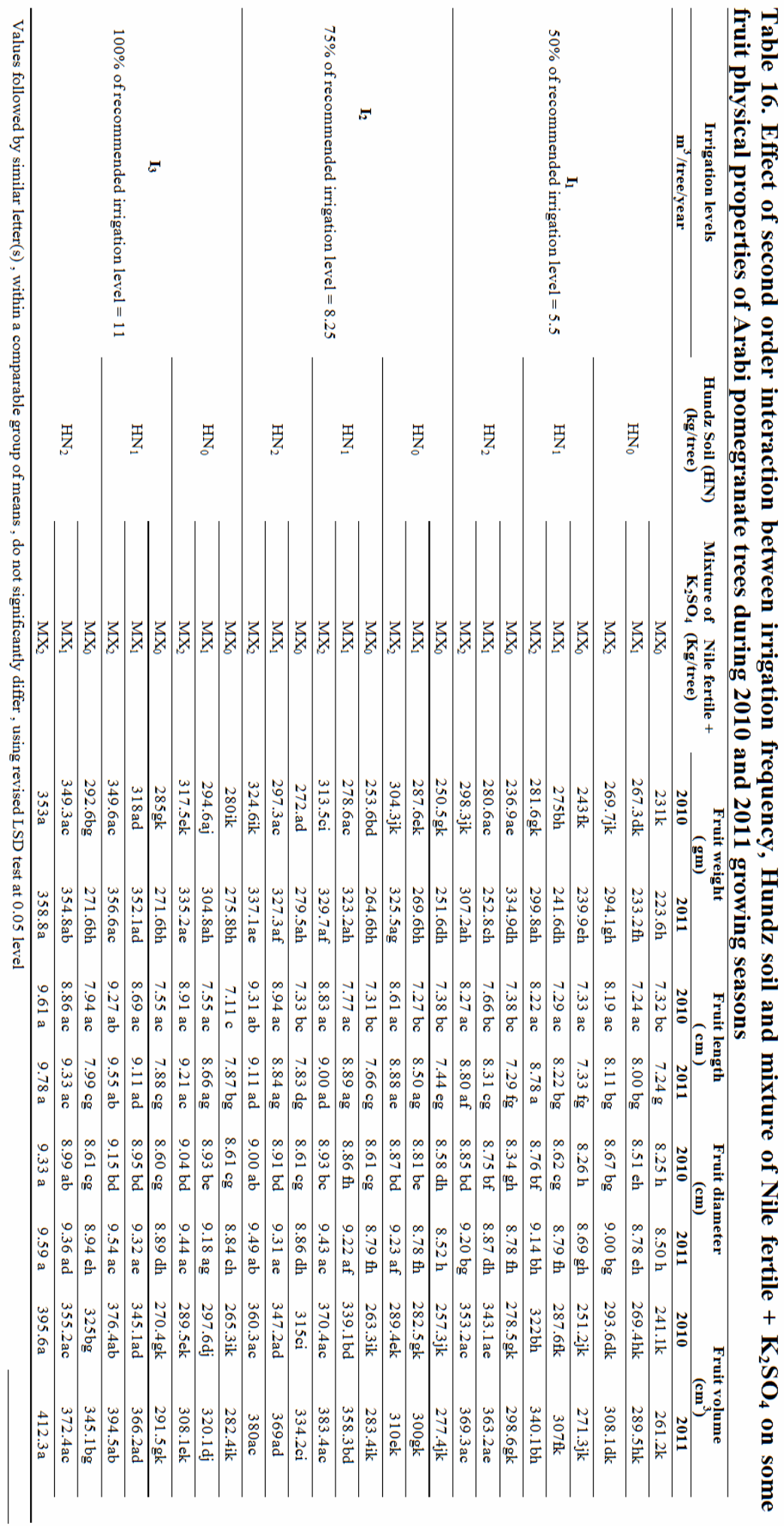




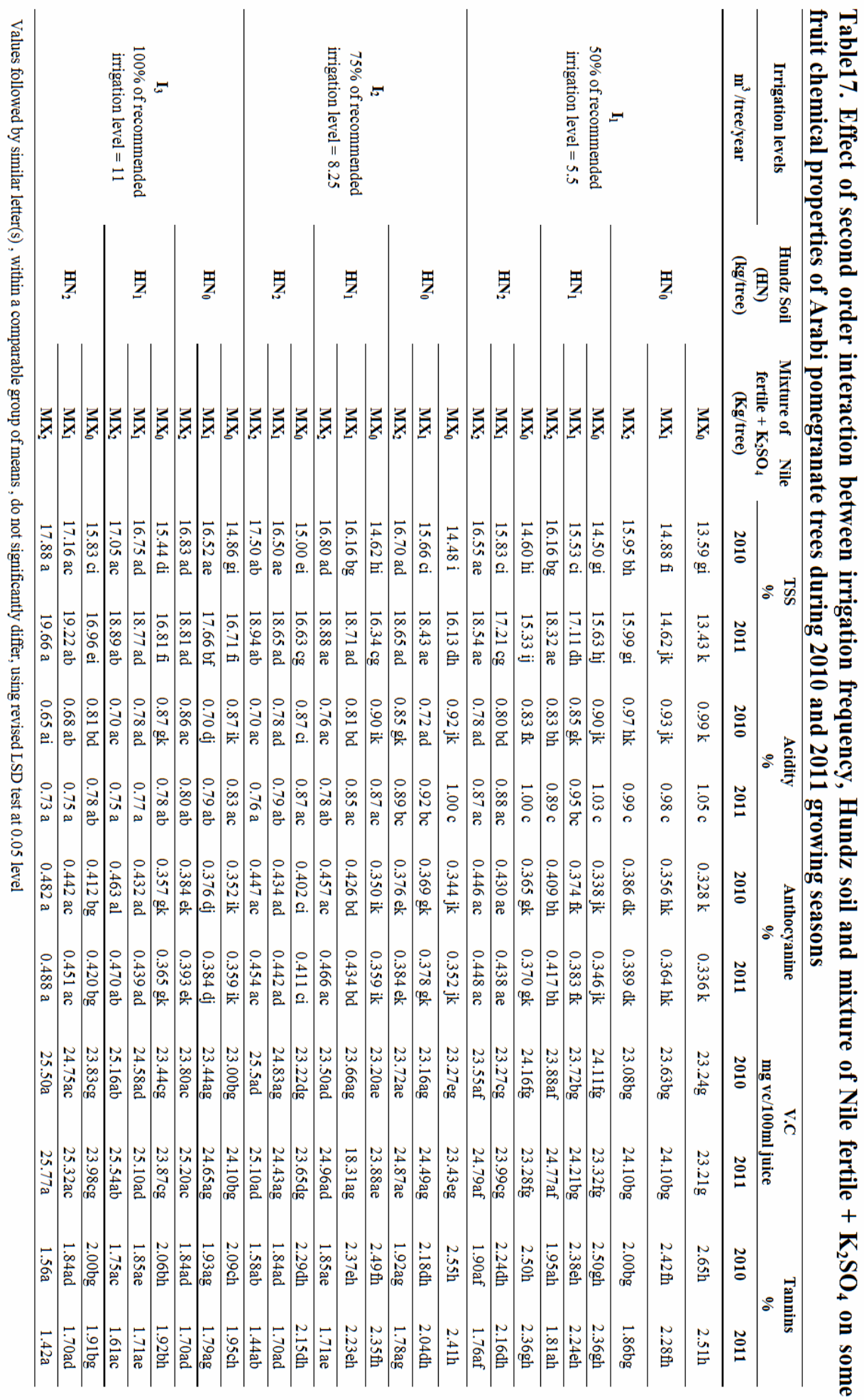




\subsection{Fruit quality properties}

The results of the first-order interaction effects of irrigation frequency, Hundz soil and (Nile fertile + $\mathrm{K}_{2} \mathrm{SO}_{4}$ )on fruit physical and chemical properties of pomegranate are shown in Tables (11 and 12).

As related to the interaction effect, highest irrigation level $11 \mathrm{~m}^{3} /$ tree /year) combined with the highest rate of Hundz soil $(10 \mathrm{Kg} /$ tree $)$ or combined with highest rate of mixture Nile fertile $+\mathrm{K}_{2} \mathrm{SO}_{4}(2 \mathrm{Kg}+500 \mathrm{gm})$ caused a significant increase in fruit weight, dimensions, TSS, anthocyanin and V.C. and decreased acidity and tannins content. Reversely, $5.5 \mathrm{~m}^{3} /$ tree /year level of irrigation without application of $\mathrm{HN}\left(\mathrm{I}^{1} \times \mathrm{HN}_{0}\right)$ or $\mathrm{NF}+\mathrm{K}_{2} \mathrm{SO}_{4}$ $\left(\mathrm{I}_{1} \times \mathrm{MX}_{0}\right)$ gave the least significant values of the above mentioned characters in both seasons. Similar trend of response was obtained with the combination between $8.25 \mathrm{~m}^{3}$ /tree /yearand $\mathrm{HN}$ at higher rate $\left(\mathrm{I}_{2} \times \mathrm{HN}_{2}\right)$ in enhancing fruit physical and chemical properties except fruit diameter in the $1^{\text {st }}$ season and V.C in the $2^{\text {nd }}$ one. Similarly, combination treatment $\left(\mathrm{I}_{2} \times \mathrm{MX}_{1}\right)$ or $\left(\mathrm{I}_{2} \times\right.$ $\mathrm{MX}_{2}$ ) gave higher fruit quality except acidity and tannin content in both seasons as comparing with $100 \%$ of the recommended irrigation solely. The results clarified the beneficial effect of such soil conditioners in increasing hydraulic conductivity and water diffusivity of sandy soils which reflected on yield and fruit quality(Laila Ali et al., 2009).

The interaction effects between $\mathrm{HZ}$ soil and the mixture from(NF $+\mathrm{K}_{2} \mathrm{SO}_{4}$ ) on fruit physical and chemical properties are presented in Tables (11\& 12). The statistical analysis of the obtained data revealed that the treatment combinations had significant effects on fruit quality in both seasons. The Application of $10 \mathrm{Kg}$ /tree $\mathrm{HN}$ soil combined with $2 \mathrm{Kg} \mathrm{NF}+500 \mathrm{gm} \mathrm{K}_{2} \mathrm{SO}_{4}$ was favorable for trees to express their best performance on fruit physical and chemical characters. Laila - Ali et al., (2009) found that the combination treatments between organic and inorganic soil conditioners increased weight of wheat grains.

\section{3-Second-order interaction effects:}

The results presented in Tables (13 to 17) illustrated the effects of the second-order interactions among irrigation levels, Hundz soil and the mixture of Nile fertile $+\mathrm{K}_{2} \mathrm{SO}_{4}$ on vegetative growth leaf chemical composition, flowering, fruiting, yield and fruit quality of pomegranate trees in 2010 and 2011 seasons.

Data indicated generally that the differences among the mean values of the various treatment combinations of pomegranate growth and productivity were found significant. The best treatment combination was gained from using the highest irrigation level $\left(11 \mathrm{~m}^{3} /\right.$ tree /year $)$ and $10 \mathrm{Kg}$ /tree Hundz soil plus $2 \mathrm{Kg}$ /tree Nile Fertile + $500 \mathrm{gm} \mathrm{K}_{2} \mathrm{SO}_{4}\left(\mathrm{I}_{3} \times \mathrm{HN}_{2} \times \mathrm{MX}_{2}\right)$ which resulted in the highest mean values for all vegetative growth characters, leaf N P K, chlorophyll and RWC, yield and all fruit quality except leaf proline, juice tannins and acidity in both seasons. Date also indicated that the application of Hzsoil combined with mixture of $\left(\mathrm{NF}+\mathrm{K}_{2} \mathrm{SO}_{4}\right)$ at both highest levels for each of them and irrigated with moderate irrigation level $8.25 \mathrm{~m}^{3} /$ tree/year gave best growth and produced higher fruit quality as compared with tree irrigated with $100 \%$ from recommendedwater level without soil conditioners $\left(\mathrm{I}_{3} \times\right.$ $\mathrm{HZ}_{0} \times \mathrm{MX}_{0}$ ). Similar effects of interactions between the application of $\mathrm{HN}_{2}$ and $\mathrm{MX}_{2}$ under least irrigation treatments $5.5 \mathrm{~m}^{3} /$ tree/year on the previous characters of fruit.Those results could be attributed to the role of organic or and inorganic soil conditioners in mineralenrichment,active organic compounds and bio substances which have the ability to chelate nutrients as available strategic storehouse and in turn reflected positively on development of crop yield and its components.

\section{CONCLUSION}

As a conclusion, pomegranate trees growth, flowering, fruit characteristics were improved in some treatments, especially the low level of irrigation when combined with soil conditioners Hundz soil or NF + $\mathrm{K}_{2} \mathrm{SO}_{4}$.

Eventually, it can be recommended that for planting pomegranate trees in the new reclaimed area to add 2 $\mathrm{Kg} /$ tree combined with $2 \mathrm{Kg}$ Nilefertile $+\mathrm{K}_{2} \mathrm{SO}_{4}$ under irrigation level $8.25 \mathrm{~m}^{3} /$ tree/year.

\section{REFERENCES}

Abbas,W.A. (1999). Effect of some additives on soil to tolerance of olive plants to salinity.M.SC.Thesis, Faculty of Agric. Cairo Univ.

Abd-Allah, M. A.(1997). Management and fertilizer of salt soils under limited water supply. M.SC. Thesis, Faculty of Agric., Al-Azhar Univ.

Association of Official Analytical Chemists (AOAC). (1995).Official method of analysis, $15^{\text {th }}$ ed.AOAC International Arlington, Verginia,USA.

Azzam,R.R.,Ayoup, Khallafollah and H. Moawad (1987). Field application of polymeric gel, RAPG in desert plantation.Third Internaional Conf. on Radiation Processing for plastic and rubber.Lodbroke Hotel, Warwick, UK Nov.2-4 UK.

Badr, M.A. (1992): Effect of soil management and fertilizer treatments on salt movement and accumulation in root zone and their encountered effect on crop yeild. M.Sc. Thesis, Faculty of Agriculture, Al-Azhar University. 
Beaumont P. (1993). Dryland Environmental Management and Development. Routledge, London and New York pp.536:210-215.

Bres, W. and Weston, A (1993). Influence of gel additives on nitrate, ammonium and tomato growth in a soilless medium Hort, Science, 28: 1005-1007.

Chapman, H. D. and R. H. Pratt (1961). Method of analysis for soil, plant and root: shoot ratios. J. Hort.Sci.46:121130.

Chauhan P.S., Sud A., Sharma L.K. and Mankotia M.S. (2005).Studies on the effect of micro-irrigation levels on growth, yield, fruit quality and nutrient assimilation of Delicious apple. Proc. VII th on TZFTS. Acta Hort., 696;193-196.

Chopade S. O., Gorantiwar S. D.,PampattiwarP.S.andSupe V.S.(2001). Response of pomegranate to drip, bubbler and surface irrigation method.Advanced in Hort.And Forestry. Scientific Publishers India Jodhpur, 8: 53-59.

CoHort Software. (2004). User's manual version.Cohort Tusson, Arizona USA.

Devid, A.G., Elias F., Merce M. and Moshe G.(1999). Sensitivity of continuous and discrete plant and soil water status monitoring in peach trees subjected to deficit irrigation. J. Amer. Soc. Hort. Sci., 124:437-444

Edmond, J.B. Senn T.L. Andrews, F.s. and Halfacre, R.G. (1975).The essential elements. Fundamental of Hort. Mcgraw-Hill, Book Company. $4^{\text {th }}$ ed., $131 \mathrm{pp}$

El-Aggory E.G. and SH. M. Abd-Elrasoul (2002). The biopolymer, agar agar as a soil conditioner. Egypt $\mathrm{J}$. Agric. Res., 80(1): 1-12.

El-Hefnawi, S.M. (1986). Physiological studies on guava. Ph.D. Thesis. Fac. Agric. Ain Shams Univ.

El-Iraqy M.A.;K.B.Essa and A.M. Abou El-Khashab(2006). Effect of different irrigation levels and potassium fertilization on 'winter guava'. Alex. J. Agric. Res. (51)75-83. Special Issue.

El-Khoreiby, A. M. and A.T. Salem(1989).Effect of different irrigation regimes on growth, fruiting and fruit quality of seedy guava trees, Ann. Agric. Sci. Fac. Ain Shams Cairo 34(1)133-321.

El-Said, M.E.; I.SaadEldin; V.F.Noaman and S. sari ElDeen(1993). Different water regimes Annl. Agric. Sci. Moshtohor, Vol. (31) 11-19.

Eman, Abd-Ella(2006). Effect of soil conditioners and irrigation frequency on the growth of Manzanillo olive seedlings.J. Adv. Agric. Res. Fac. Agric. Saba Bacha.719736.

Evenhuis, B. (1976). Nitrogen determination Dept. Agrci. Res. Royal.TropicalInstAmsterdam.

Evenhuis, B. and P.W. Dewaard (1980). Principal and practices in plant analysis. F.A.O. soil Bull.: 152-162.

Fitzpatrick, E.A.(1986). An Introduction to Soil Science. $2^{\text {nd }}$ ed. John Wiley\&Sons.Inc.,New York.pp.108-137.
Gething, P.A. 1986. Improving returns from nitrogen fertilizer "The potassium nitrogen partnership" IPI research topic No., 13. International Potash institute, Bern/ Switzerland.

Hilal, M. H., Abdel-Fattah, A. and Korkor, S. A.(1997) .Effect of fine and granular sulphur application on root depth and yield of Lupine in sandy soils. Middle eastSulphur Symposium. Cairo, Egypt. Pp, 207-216.

Hoda, A. Khalil (2005).Effect of water stress and the soil conditioner, PAM, on growth and chemical composition of young orange and Manzanillo olive trees. M.SC. Thesis. Faculty of Agric. Alex.Univ.

Hsia, C.L.; B. S. LUH andC.B. Chickester .(1965). Anthocyanine in freestone peaches. J. food, Sci, 30: 5-12.

Hussein S.M. (2004). Effect of different irrigation levels on the Le-cont pear trees. Ph.D. Thesis, Fac. Of Agric., Cairo Univ. Egypt.

Im, J. N.(1982). Organic materials and improvement of soil physical characteristics. F.A.O. Soil Bull.,pp.106-117.

Kandil, E. A.and U.S. El-Feky(2006). Effect of soil matric potential on Canino apricot trees in sandy soil under drip irrigation. J. Agric. Sci. Mansoura Univ., 31(9)5867-5880.

Kay-Shoemak, L.; Westwood, Ekilpatrick, I and Harris,K.(2000). Exchangeable ammonia and nitrate from different nitrogen fertilizer prepartion in polyacrylamidtreatment and untreated agricultural soils. Biology and fertility of soils, 31: 245-248.

Khalifa, E.M.,Abo-Zeid,M.I.; Nassar, I. N. and Esmail, S.M.(1997). Effect of a sugarcane industry by-product (filter mud cake)on some physical properties of soils. The First Scientific Conference of Agric. Sci. Fac. Agric. Univ.13-14 December Vol. (1):467-482.

Khattab, M.M. Shaban, A.E. El-Shreif A. A. and El-Souda A.S.(2010). Effect of irrigation levels on growth and fruiting ofManfalouty pomegranate trees. Bull. Fac. Agric. Cairo Univ. 61:8-16.

Laila - Ali, K.M. Mahrous, S.E. and Ramadan H.M. (2009). Effect of organic and inorganic conditioners on P-release from rock phosphate and its impact on wheat plant. Egypt J. agric. Res.87(1):93-110.

Lawand B.T. and Patil V.k. (1996).Effect of different water regimes on fruit quality of pomegranate (Punica granatum L.).International Journal of Tropical Agriculture. 14: (1/4): 153-158.

Lindhauer, M.G. (1985).Influence of K nutrition and drought on water relation and growth of sunflower (Helianthusannus L.). Z. pflanzenernahr.Bodenk, 153, 2532.

Marschner, H. (1995). Mineral nutrition of higher plant $2^{\text {nd }}$ ed. Academic, Prees, London.

Mohamed R. El-Shenawi\& Mohamed E. Moursy (2010).The effect of organic manure and potassium fertilizers on growth, yield and fruit quality of Anna trees. Alex., Sci. Exchange J. Vol.31 No.4404-415. 
Murphy, J. and J.P. Riley (1962). A modified single solution method for the determine of phosphorus in natural water. Ann.Chem. Acta.27: 31-36.

Saddik M.A. and K.M. Laila - Ali(2004). Effect of some natural soilamendment on some soil physical properties, peanut and carrot yield in sandy soil. Egypt J. Agric. Res., 82(2).

Salisbury, F.B.and Rose C.W. (1985). Plant Physiology. Wadsworth Pub.Co.,USA.185pp.

Sherin-Attia, A.A.(2002).Studied on growth of olive plants under salt strees. Ph.D. Thesis Fac. of Agrci.Cairo Univ.

Silberbush, M.; E. Adar, Y. DeMalach (1993). Use of an hydrophilic polymer to improve water storage and availability to crops grown in sand dunes. 1. Corn irrigated by trickling. Agric. Water Management, 23: 303313 .

Singh, T.N.; L. G. Poleg and D. Aspinall. (1973). Stress metabolism. 1-Nitogen metabolism and growth in the barley plant during water stress. Asut. J. Biol. Sci.(26):4556.
Smart, R. E. and G.E. Bingham(1974). Rapid estimates of relative water content. Plant Physiol., 53:258-260.

Steel, R.G.D. and J.H. Torrie (1980). Procedures of statistics $2^{\text {nd }}$ ed. McGraw Hill Book Co., Inc. New York, USA.

Suelter, C.H.(1970).Enzymes activated by monovalent cation. Science, 168, 789-795.

Wael A.A. Ali (2005). Improving growth and production of olive orchard under desert conditions.Ph.D.Thesis Agric. Sci.,Cairo Univ.

Wafaa El-Etr, M.A.(2001)Biological weathering of K-bearing miners. Ph.D.Thesis Agric., AinShamsUinv., Egypt.

Wallace, A and G. Wallace (1986). Effect of soil conditioners on emergence and growth of tomato, cotton and lettuce seedlings. Soil Sci., Vol.141.No(5). *Winton, A.H. and K.B.Winton (1945).Analysis of food. Wiely,New York p:572

Yadava, U.L. (1986). A rapid and non-destructive method to determine chlorophyll in intact leaves.HortSci., 21:14491450 . 


\section{| (1)

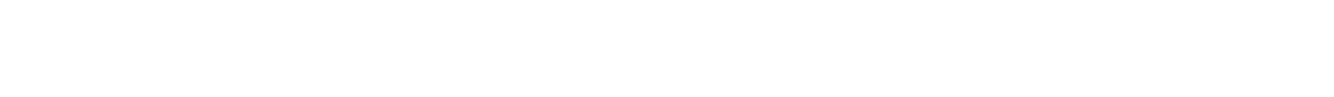 لالستصلاح الميثة \\ آلآن السيد كلل عبد اللاه}

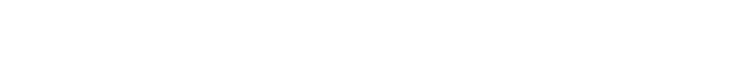

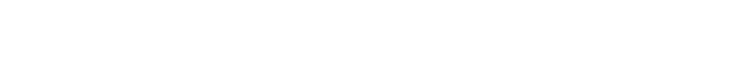

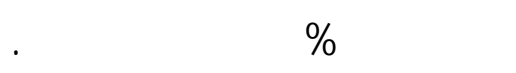

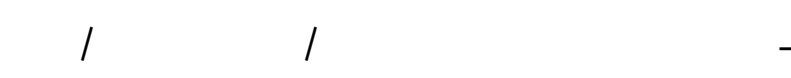

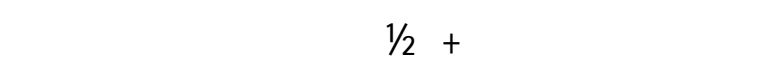

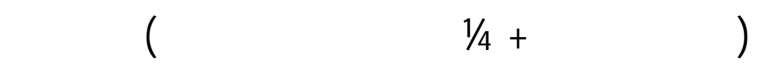

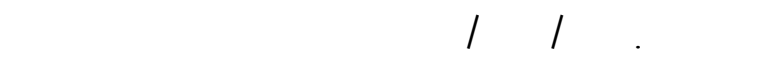

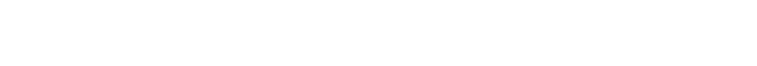
أمتر "مثجروكسنه.

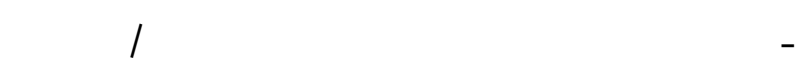

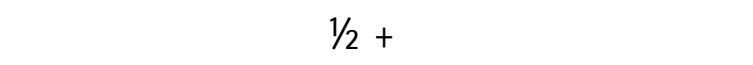

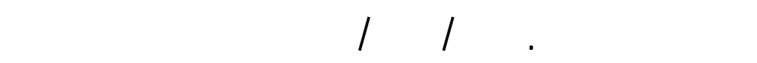

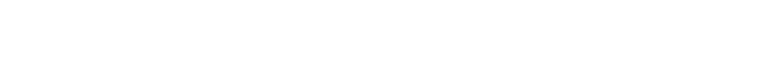

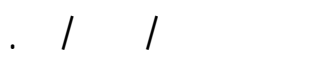

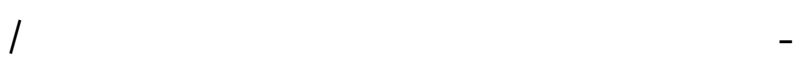

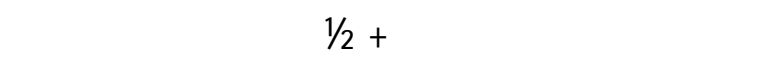

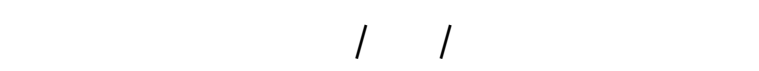
مصول وجوده للثمار.

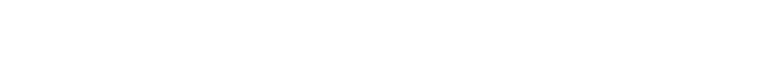

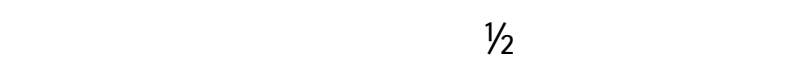

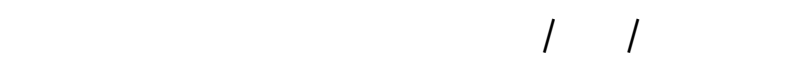

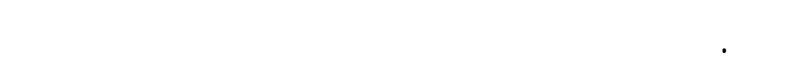

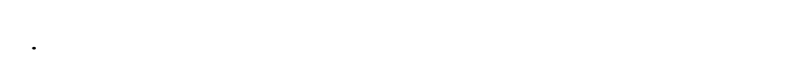

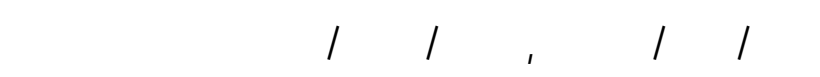

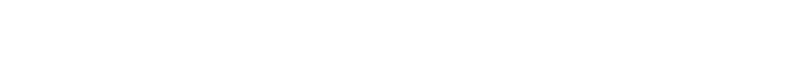
الأستصلاح.

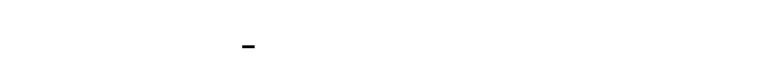

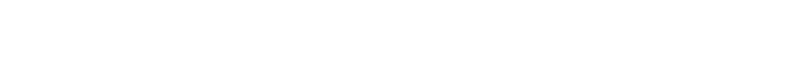

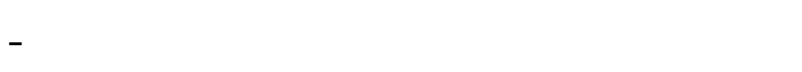

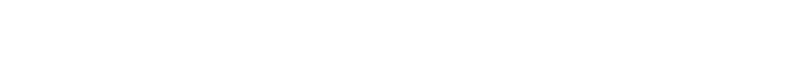

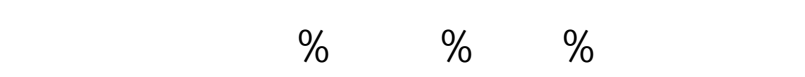
ثلاثة مستويت من لهن التره هاتسول ( بدون لهن أو 0 أو

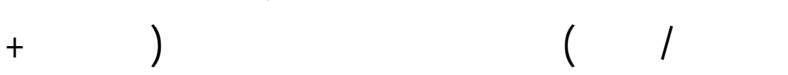

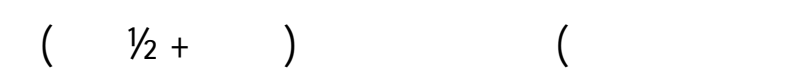

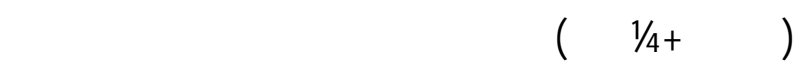
العولل الثلاث إلمرويه على بض صفلت النمو الهضرى والزهرى ومكونت الأورق وصفلت جوقة الثمار والصول خلل مولى الدرلسة وقد أوضمت الدرلسه التنائج التاليه.

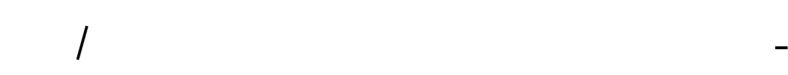

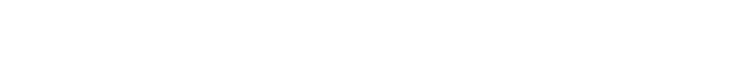

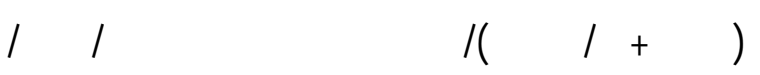

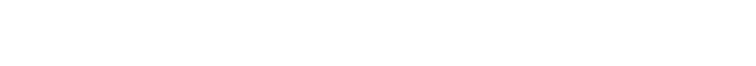

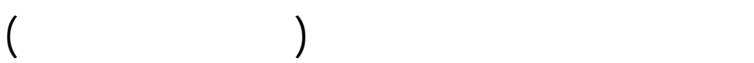

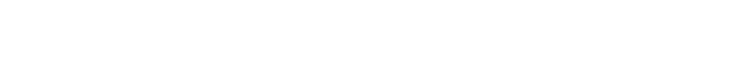

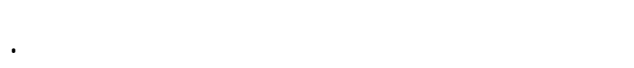

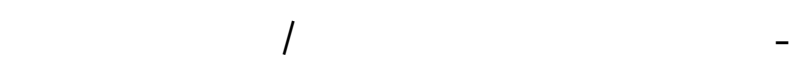

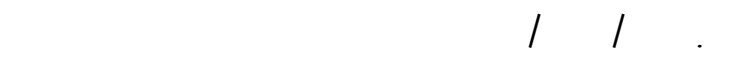
آضرى ومكونت الأورق والثمار وكذلك الصصل

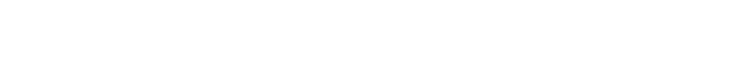

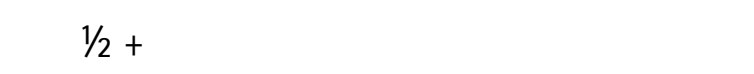

